\title{
New insights about the Upper Jurassic - Lower Cretaceous sedimentary successions from Asturias (NW Iberian Peninsula)
}

\author{
B. González-Fernández ${ }^{1 *}$, E. Menéndez-Casares ${ }^{1}$, V. Vicedo², C. Aramburu³ , E. Caus ${ }^{4}$ \\ ${ }^{1}$ Departamento de Explotación y Prospección de Minas, Universidad de Oviedo. C/Independencia, 13, 33004 Oviedo, Spain. \\ ${ }^{2}$ Museu de Ciències Naturals de Barcelona (Paleontologia). Passeig Picasso s/n. 08003 Barcelona, Spain. \\ 3 Departamento de Geología, Universidad de Oviedo. C/ Jesús Arias de Velasco, s/n, 33005 Oviedo, Spain. \\ 4 Departament de Geologia (Paleontologia), Universitat Autònoma de Barcelona, 08193 Cerdanyola del Vallès, Spain. \\ e-mail addresses: mbeagf@uniovi.es (B.G.-F., *corresponding author); ecasares@uniovi.es (E.C.); vicent.vicedo@bcn.cat (V.V.); carambur@geol.uniovi.es (C.A.); \\ esmeralda.caus@uab.es (E.C.)
}

Received: 25 July 2013 / Accepted: 3 May 2014 / Available online: 30 October 2014

\begin{abstract}
Detailed mapping of the Jurassic to pre-Albian deposits of central and eastern Asturias (NW of the Iberian Peninsula) allowed several Upper Jurassic and Lower Cretaceous outcrops, previously assigned to other ages, to be identified. Where possible, these outcrops were correlated with the well-known sequences outcropping on the Asturian coast. A new Jurassic stratigraphic unit, the Miyares Formation, was defined, consisting of a conglomerate Lower Unit, a Middle Unit composed mainly of oolitic limestones and an Upper Unit comprising bioclastic and marly limestones with a rich larger foraminiferal fauna. The Lower Unit is interpreted as deposited in a fan delta, the Middle Unit represents a shallow marine high-energy environment, and the Upper Unit deposited on a restricted shallow marine platform. The shallow-water foraminiferal assemblage from the Upper Unit is attributed to the Tithonian and the oldest Cretaceous rocks are Barremian. Therefore, there is a stratigraphic gap recorded in the study area, which might correspond to the latest Jurassic to Early Cretaceous pro parte timespan.
\end{abstract}

Keywords: Late Jurassic, Early Cretaceous, Larger Foraminifera, NW Spain

Resumen

Una cartografía geológica detallada de los depósitos jurásicos y cretácicos pre-albienses ha permitido identificar varios afloramientos del Jurásico Superior y del Cretácico Inferior, asignados previamente a otras edades. Donde ha sido posible, estos afloramientos han sido correlacionados con las sucesiones bien conocidas que afloran en la costa asturiana. Se ha definido una nueva unidad, la Formación Miyares, formada por una Unidad Inferior conglomerática, una Unidad Media mayoritariamente de calizas oolíticas y una Unidad Superior de calizas bioclásticas y margosas con abundantes macroforaminíferos. La Unidad Inferior se interpreta como depósitos de fan delta, la Unidad Media representa un ambiente marino somero de alta energía, y la Unidad Superior fue depositada en una plataforma marina somera restringida. El conjunto de foraminíferos de agua somera de la Unidad Superior se atribuye al Titoniense y las rocas más antiguas del Cretácico son del Barremiense; existe por lo tanto, en el área de estudio, una laguna estratigráfica que abarca la parte terminal del Jurásico y una parte del Cretácico Inferior.

Palabras clave: Jurásico Superior, Cretácico Inferior, macroforaminíferos, NW España

\section{Introduction}

The boundary between the Jurassic and Cretaceous systems in Europe (western Tethys) has been controversial almost since the establishment of the first chronostratigraphic scales, because of difficulties in correlating the stratigraphic sections of $\mathrm{N}$ and S Europe (Boreal and Tethyan realms, respectively; Gradstein et al., 2012 and the papers cited therein).
The extreme ammonite faunal provincialism during the latest Jurassic and the earliest Cretaceous encouraged the definition and use of several stages which more or less overlap in time (for instance: Portlandian, Purbeckian, Volgian, Tithonian, Bolonian, etc.). In some cases, such as the Purbeckian stage, its definition was a reflection more of the different facies types than of chronostratigraphic intervals (for more information on the subject see Cope, 2008). In 1990 the ac- 
ceptance by the International Commission on Stratigraphy (Subcommittee on Jurassic Stratigraphy) of the Tithonian (defined in SE France, Tethyan realm) as the last stage of the Jurassic system marked the first step towards the establishment of the Jurassic-Cretaceous boundary between the Tithonian and Berriasian stages, respectively (Wimbledon et $a l ., 2011$ and the papers cited therein).

The beginning of the Cretaceous Period is established at the first appearance of the ammonite Berriasella jacobi, which coincides practically with the base of Calpionellid Zone B (marked by the acme of Calpionella subalpina) and the later part of the polarity Chron M19N, at $145.5 \pm 4.0 \mathrm{Ma}$ (see Gradstein et al., 2004; for further details). However, the problem associated with the identification of the Jurassic - Cretaceous boundary persists for shallow water marine and continental sedimentary successions in which biostratigraphic data are derived from several groups of benthic macrofossils, foraminifera, ostracods and charophytes that are uncorrelated to ammonoid or planktonic zonations. This is especially evident for larger foraminifera. Although there are a number of papers that tackle the Jurassic-Cretaceous transition, the precise temporal distribution of taxa remains uncertain (see, for instance, Bassoullet, 1997). This is exacerbated by the different extensions of the underlying stage, the Kimmeridgian in Boreal and Tethyan geological time scales (see Fig. 19.2 in Gradstein et al., 2004). These difficulties of correlation and dating are very obvious in Asturias (NW Spain), where, despite the existence of sedimentary successions representing both the Jurassic and Cretaceous periods, the boundary between them is unclear and, usually, their assignment to the former or the latter is arbitrary (Ramírez del Pozo, 1969; Dubar et al., 1971 and the works cited therein; Suárez Vega, 1974).

New geological mappings carried out in the central and eastern Asturias have revealed outcrops containing shallow marine fauna and which provide new information about the Jurassic-Cretaceous transition in the NW of the Iberian Peninsula.

Therefore, the aim of this work is to provide new data on the stratigraphy and palaeontology of the Late Jurassic-Early Cretaceous transition. The study and reinterpretation of several outcrops has provided new information concerning: a) the distribution of Upper Jurassic-Lower Cretaceous sedimentary facies in the central and eastern Asturias; b) a facies correlation between the studied outcrops and the well-known Jurassic and Cretaceous sections on the coast (between Gijón and Ribadesella); and c) the presence in Asturias of a previously unknown Upper Jurassic rich larger foraminifera assemblage.

Based on facies distribution and ages, a depositional history of the Asturian Basin (sensu Lepvrier and MartínezGarcía, 1990) during the Late Jurassic-Early Cretaceous is suggested.

\section{Geological setting and previous works}

The studied Jurassic and Cretaceous outcrops belong to the Mesozoic-Cenozoic Cover of the Cantabrian Mountains, and are located in the vicinity of the villages of Villamayor, Vega de Sariego and Pola de Siero (Fig. 1). The succession attributed to the Jurassic corresponds to two superposed sedimentary megasequences bound by a major disconformity (Valenzuela et al., 1986; Fig. 2). The lower megasequence comprises the Villaviciosa Group and includes the Gijón and Rodiles Formations; the upper megasequence corresponds to the Ribadesella Group and is composed of the La Nora, Vega, Tereñes and Lastres Formations (Valenzuela et al., 1986). The Gijón and Rodiles Formations have been attributed to the upper Rhaetian-lower Bajocian (Ramírez del Pozo, 1969; Dubar et al., 1971; Suárez-Vega, 1974; Barrón et al., 2002, 2006). The age of La Nora and Vega Formations is controversial. Valenzuela et al.(1986) suggest a Dogger age, while Schudack and Schudack (2002) indicate an age "somewhere between the late Oxfordian and late Kimmeridgian" for the Vega Fm. The Tereñes Fm. has been attributed to the early Kimmeridgian by Valenzuela et al.(1986). Schudack and Schudack (2002), based on ostracod associations, report a late Kimmeridgian age for these deposits. The age of the Lastres Fm. is also controversial. Based on the scarce ammonoids found in the middle part of the formation, Dubar and Mouterde (1957) and Suárez-Vega (1974) specify a late Kimmeridgian age (Eudoxus zone), and Ramírez del Pozo (1969) assigns an early Portlandian age to the upper part of the Lastres Fm. Oloriz et al.(1988) cites a single specimen of ammonoid from the early Kimmeridgian (Cymodoce zone) in the lowest part of the unit. However, Schudack and Schudack (2002) identified ostracod associations, indicating an upper Kimmeridgiann age for the lower and middle part of the formation and a lower Tithonian age for its upper part.

The Cretaceous succession has been divided by GonzálezFernández et al.(2004) into ten lithostratigraphic units, but in the present work only the two lower ones were studied: the Peñaferruz and Antromero Formations (Fig. 3). The Peñaferruz Fm. is attributed to the Wealdian facies by Karrenberg (1934) and Schroeder and Wienands (1966). Ramírez del Pozo (1969) assigns an early Cretaceous (pre-Aptian) age to this formation, while González-Fernández et al.(2004) suggests a late Barremian-Aptian age. Recent palynological studies (Barron, 2011, pers. comm.) indicate an early Barremian age. The Antromero Fm. has been dated as Aptian, but an upper Barremian age cannot be excluded (Karrenberg, 1934; Schroeder and Wienands, 1966). The Asturian Jurassic and Lower Cretaceous sedimentary successions crop out in the Asturian Basin which represent the western part of an epicontinental sea extending between the Iberian Plate margin to the southwest and the Armorican Massif to the north. The sedimentation in this basin was largely controlled by tectonic 


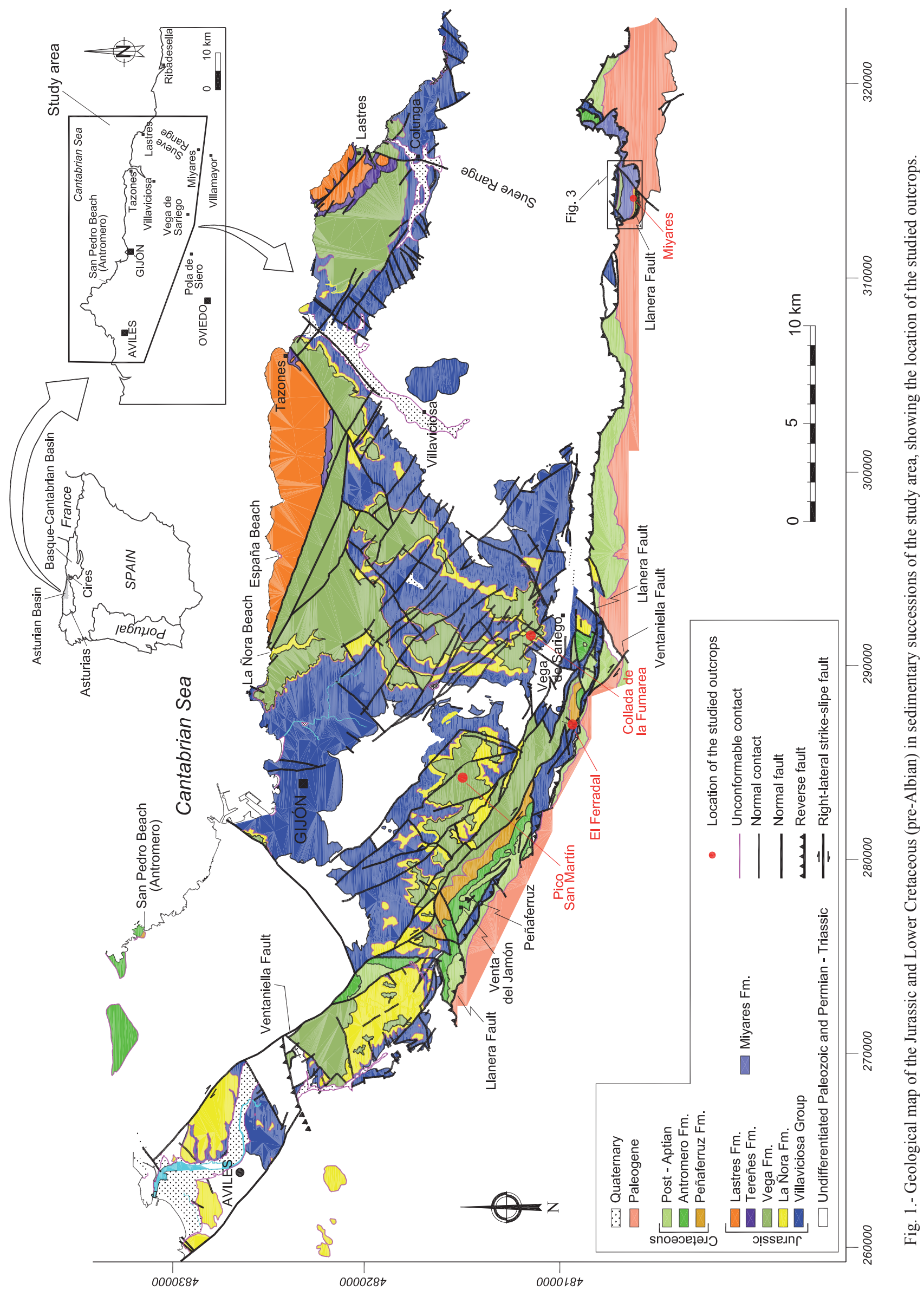




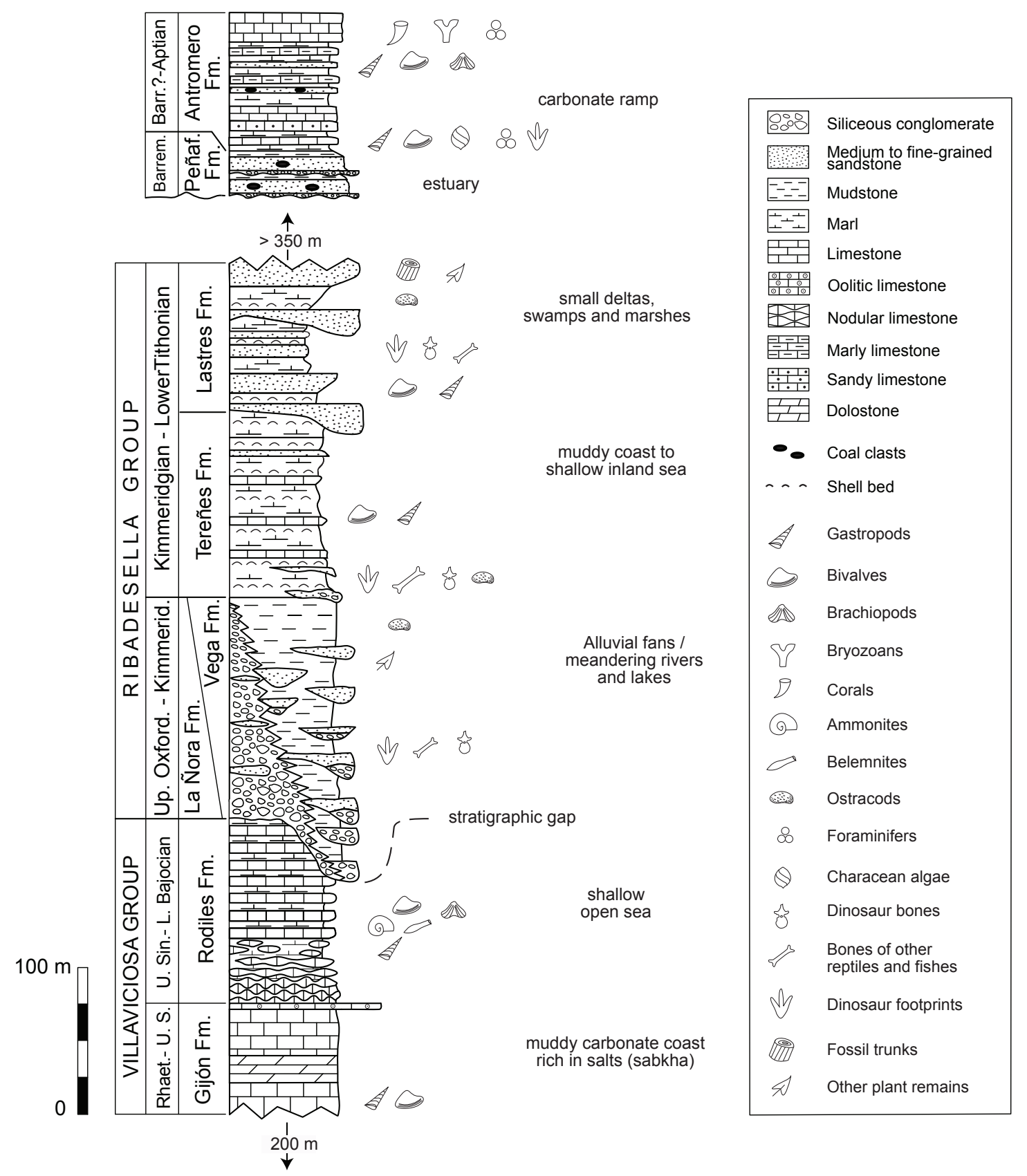

Fig. 2.- Schematic stratigraphic section of the Asturian Jurassic and Lower Cretaceous (pre-Albian) deposits. After data from Valenzuela et al.(1986), Barrón et al.(2002, 2006), Schudack and Schudack (2002) and González-Fernández et al.(2004).

activity linked to successive phases of the rifting of the Bay of Biscay (Aurell et al., 2002, 2003).

From a tectonic point of view, the most relevant structure in the study area is the Llanera Fault (Fig. 1), an extensional pre-Albian structure that caused the separation of a hanging wall to the north and a footwall to the south. The pre-Albian Mesozoic succession described above was preserved on the hanging wall block, while the post-rift rocks (post-Aptian) directly and unconformably overlie Paleozoic or Triassic rocks on the footwall block. This fault was later inverted during Palaeogene times (Alonso et al., 1995, 1996).

\section{Materials and methods}

The fieldwork consisted of detailed geological mapping and stratigraphic study of the outcrops localized at Miyares, El Ferradal and Collada La Fumarea that were previously recorded by other authors but assigned to other ages. Additionally, the data collected by Ramírez del Pozo (1969) concerning the Pico San Martin-Santa Cecilia outcrop, partially covered at present, have been reinterpreted. These are isolated outcrops, which, in some cases, are of reduced thickness and covered by dense vegetation. A detailed stratigraphic 


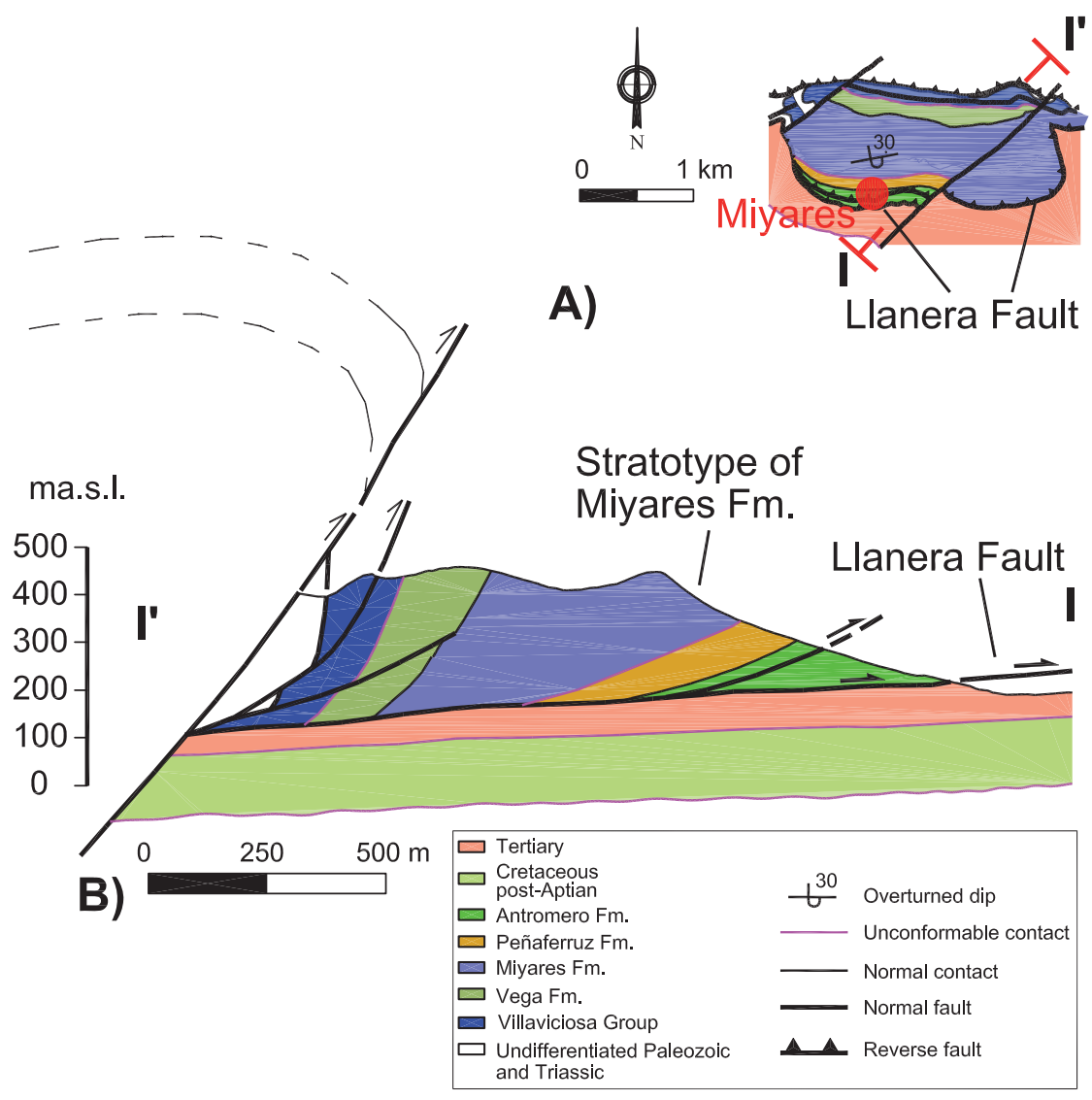

Fig. 3.- Detailed geological map (A) and geological cross section (B) of the Miyares outcrop (stratotype of the Miyares Fm.), showing its current location on the overturned limb of a thrust-related anticline. Note the overturned stratigraphic polarity of the stratotype. See location and legend in Fig. 1.

section logging was only possible for the Miyares outcrop. A total of 67 samples of hard rock were collected, from which 132 thin sections were prepared for microfacies and microfossils analysis. Well-known coastal outcrops (España Beach, San Pedro de Antromero Beach and the cliffs in the west of Ribadesella) were also studied and sampled in order to obtain material for comparison. The fossil specimens included in the figures are housed in the collection of Palaeontology of the Museu de Ciències Naturals de Barcelona, under the acronym MGB. Supplementary material has been deposited in the palaeontological collections of the Universitat Autònoma de Barcelona (Bellaterra, Spain).

\section{Description of the outcrops}

\subsection{Miyares outcrop}

This outcrop is located north of the locality of Miyares and south of the Sueve Range (Fig. 1). It lies on the overturned limb of a thrust-related anticline with an $\mathrm{E}-\mathrm{W}$ direction and southern vergence (Fig. 3). The sedimentary succession is $800 \mathrm{~m}$ thick and the strata have an average overturned dip of $30^{\circ}$. This outcrop has previously been ascribed to the Cretaceous (Beroiz et al., 1973). From bottom to top, four stratigraphic units have been distinguished (Fig. 4):

\section{Vega Formation}

In the Miyares outcrop only the upper part of this unit is visible, consisting of red and grey lutites and sandstones, and limestones with charophytes, ostracods and gastropods (Fig. 4). This succession has been interpreted by García-Ramos et al. (1979) representing a meandering fluvial environment with occasional ponds.

\section{Miyares Formation}

This succession does not correspond to any other stratigraphic unit previously identified for the Mesozoic of Asturias (see Valenzuela et al., 1986 and Gonzalez-Fernandez et al., 2004). A new geological formation is therefore herein defined. The formational name is derived from the village of Miyares, located $3 \mathrm{~km}$ north of the Villamayor (municipality of Piloña). The stratotype is located at the following UTM coordinates: $\mathrm{x}=314421, \mathrm{y}=4806840$ to the base, $\mathrm{x}$ $=313650, y=4806120$ to the top. The relationship of this unit with those established in the Late Jurassic for other sectors of the Basque-Cantabrian basin is shown in the chronostratigraphic chart in Fig. 5. The Miyares Fm. conformably overlies the Vega Fm. by means of a transitional contact, and is informally subdivided into three successive stratigraphic units (Fig. 4):

Lower Unit. The boundary between the Vega Fm. and the Lower Unit of the Miyares Fm. is marked by the first bed of the calcareous conglomerates. It consists of a $316 \mathrm{~m}$ thick 


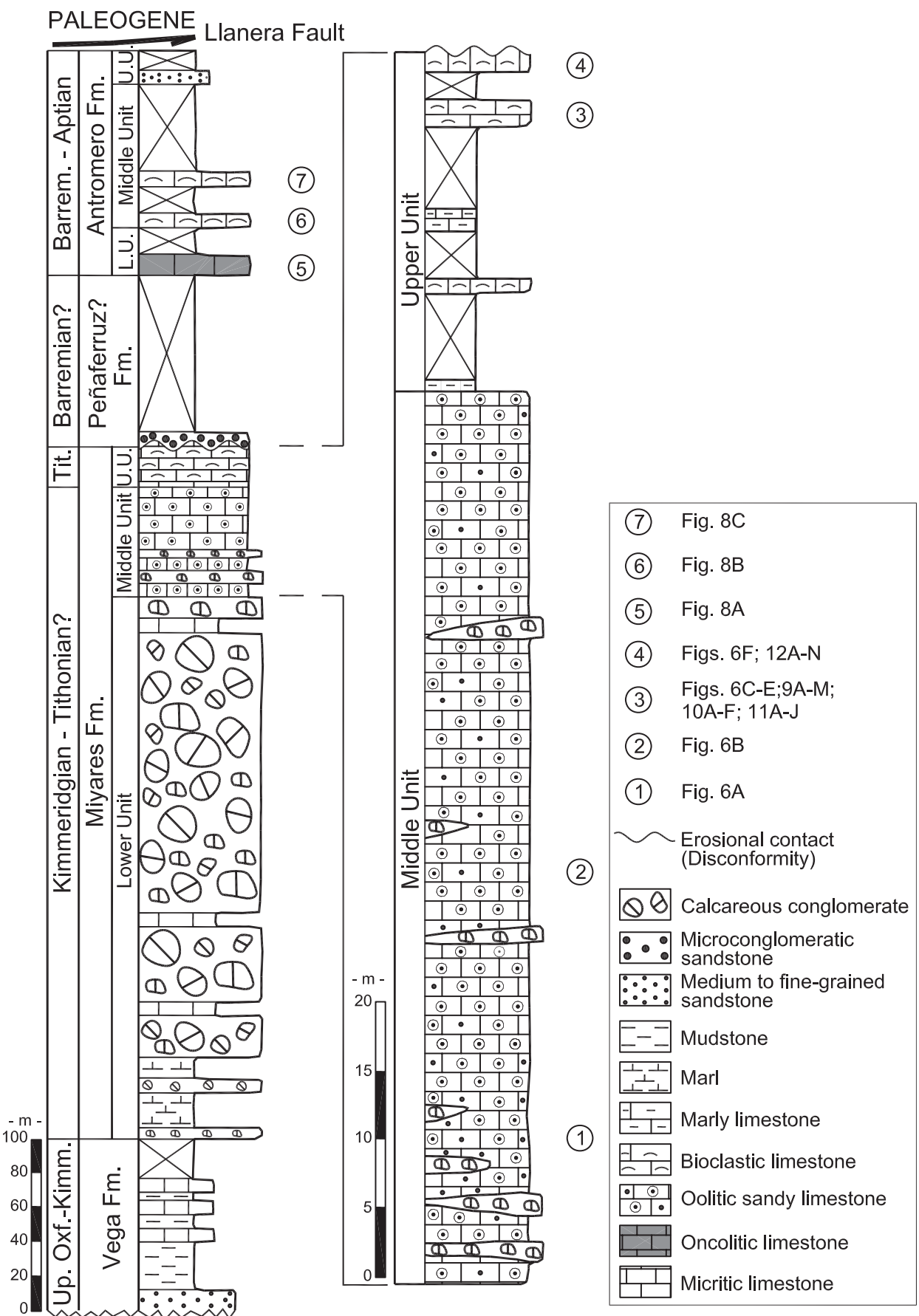

Fig. 4.- Stratigraphic log of the sectiontype of the Miyares Fm. The numbers indicate the stratigraphic position of the studied samples, the microphotographs for which are shown in Figs 6 and 8 to 13 . succession of pebble-supported calcareous conglomerates of heterometric, subspherical and sub-rounded clasts with minor intercalations of marls, limestones and, more rarely, sandstones. Most of the clasts are constituted of red and grey oolitic and micritic limestones, mainly derived from older Jurassic rocks. Some black limestone pebbles are probably derived from Palaeozoic rocks. The matrix is coarse-grained sand to microconglomerate. A microscopical study of thin sections from the limestones intercalated within the conglomerates shows microbial structures enveloping rounded micritized indeterminate fragments. Fine- to medium-grained quartz grains are also present. A probable Kimmeridgian age is suggested for the Lower Unit by mean of its stratigraphical position. The gradual transition to both the lower continental Vega Fm. and the Middle oolitic Unit, together with the lithological characteristics and thickness, suggests a possible prograding-retrograding fan depositional system. During the progradational stage would behave as an alluvial fan or fan delta (transition from the Vega Fm. to the Lower conglomeratic Unit) and in the retrogradational stage as a fan delta, resulting in a marine transgression (transition to the shallow marine carbonate facies). This cycle is attributed to extensional tectonics in the Jurassic - Cretaceous boundary such as described by Lepvrier and Martínez - García, (1990) in the 
Asturian Basin and in other parts of the Iberia ("second stage of rifting" in Mas et al., 2004).

Lithologically similar conglomerates also occur near the Jurassic-Cretaceous boundary in neighbouring regions, e.g. in the base of the Cires Fm. in Cantabria (Figs. 1 and 5), although they have been previously interpreted as alluvial fans deposited in alluvial-lacustrine basins (Robles et al., 1996).

Middle Unit. This unit is composed of $65 \mathrm{~m}$ of oolitic, occasionally sandy, limestones with thin intercalations of calcareous conglomerates at the base (Fig. 4). A detailed study of several thin sections distinguished two microfacies: a) rounded to elliptical oolitic grainstones, in which the oolites' nuclei include foraminifera (Nautiloculina, Andersenolina and small agglutinates) and Terquemella (Fig. 6A); b) bioclastic-oolitic grainstone and, more rarely, packstone, constituted of rounded fragments of bivalves, echinoderms and other micritized indeterminate fragments, pellets and oolites similar to those described in microfacies "a" (Fig. 6B). Locally, this microfacies includes foraminifera (Andersenolina and Nautiloculina) and some oncoids. Small quartz grains constitute a minor component.

The Middle Unit is interpreted as deposited in a shallow marine, high-energy environment. The rare foraminifera present in this unit do not allow a precise age to be determined, but the unit stratigraphic position suggests a possible Kimmeridgian-Tithonian age. The contact between this and the lower unit is occasionally disrupted by faults (Fig. 7) that were interpreted as synsedimentary faults, originated in the retrogradational stage of the alluvial fan-fan delta evolution by the extensional tectonics above cited.

Upper Unit. No contact was observed between this and the middle unit. It consists of $25 \mathrm{~m}$ of bioclastic limestones, alternating with partially covered marly limestones (Fig. 4). Three main microfacies have been identified within the unit. a) This microfacies comprises a peloidal packstone-grainstone, including some large fragments of oysters and other indeterminate bivalves, echinoderms, foraminifera and algae (Fig. 6C, D). Small, rounded quartz grains are also present. The most representative larger foraminifer is Anchispirocyclina lusitanica, which is accompanied by Pseudocyclammina lituus, Everticyclammina virguliana, Andersenolina gr. alpina, Nautiloculina cf. oolithica, Mohlerina bassilensis and small benthics. Salpingoporella sp., Marinella lugeoni and Cayeuxia piae are also present. b) This microfacies is a packstone-grainstone with elongated bioclasts dominated by indeterminate bivalves and echinoderms, and a lesser proportion of algae and bryozoans (Fig. 6E). Fragments of Lithocodium aggregatum are common in this microfacies. Some foraminifera from the previous microfacies are also present, but often fragmented. c) This microfacies is a wackestone (occasionally mudstone) with foraminifera, charophytes, ostracods and gastropods (Fig. 6F). Choffatella aff. tingitana is the most common foraminifer, and is associated with Feurtillia frequens and Anchispirocyclina lusitanica. The lithological and fossil characteristics of this unit suggest deposition in a shallow marine environment. Microfacies "a" and "b" correspond to a well-oxygenated marine environment with normal salinity. In contrast, microfacies "c" denotes an environment where seawater circulation was periodically restricted; the fragments of charophytes found in this microfacies suggest a nearby continental input.

The larger foraminifera found in this unit can be correlated with assemblages described in other areas of the Tethyan realm (see among others Maync, 1959; Redmond, 1964, 1965; Hottinger, 1967; Ramalho, 1971; Septfontaine, 1987), which were mainly attributed to the Kimmeridgian-Portlandian interval. However, the lack of the Oxfordian-Kimmeridgian genus Alveosepta, the abundance of $A$. lusitanica and the presence of $P$. lituus in association with $E$. virguliana may suggest a younger age than the Kimmeridgian for the Asturian assemblage. Conversely, apart from some genera which seem to span the Jurassic-Cretaceous boundary, no genera were found exclusive to the Berriasian age. Therefore, a Tithonian age is suggested for this upper unit. This foraminferal assemblage was found for the first time in Asturias although Ramírez del Pozo (1969) already reported P. lituus from the top of the Lastres Fm. at España Beach (see Fig. 1). Thus, the uppermost part of the Lastres Fm. may be correlated with the Upper Unit of the Miyares Fm. However, the abundant supply of terrigenous material to the basin in the Lastres Fm. made colonization and/or survival difficult for the majority of larger foraminifera. In contrast, the calcareous fine-grained sediments deposited in a shallow inner shelf with little terrigenous input (Upper Unit of the Miyares Fm.) represent a favourable habitat for the development of larger foraminifera. The presence of $A$. lusitanica has been cited by Rat (1959) and Ramírez del Pozo (1971) in nearby areas.

\section{Peñaferruz Formation?}

A $0.4 \mathrm{~m}$-thick microconglomeratic sandstones, attributed to the Peñaferruz Fm. by its stratigraphic position, occurs directly over the Miyares Fm. These sandstones are followed by approximately $100 \mathrm{~m}$ of a covered interval (Fig. 4). The erosive contact between both formations is presumably a disconformable surface.

\section{Antromero Formation}

The succession attributed to the Antromero Fm. has a thickness of around $130 \mathrm{~m}$ and comprises three different units (Fig. 4). The Lower Unit is constituted by microbialites formed by subspherical to ellipsoidal oncoids that can reach several centimetres in diameter. The oncoids present a concentric lamination (Fig. 8A). The presence of charophytes and the absence of marine organisms within the microbialites suggest a lacustrine environment. This unit has not been identified in the locality-type of the Antromero Fm. (San Pedro de Antromero Beach), although a similar facies appears at the base of the Antromero Fm. to the north of Pola 


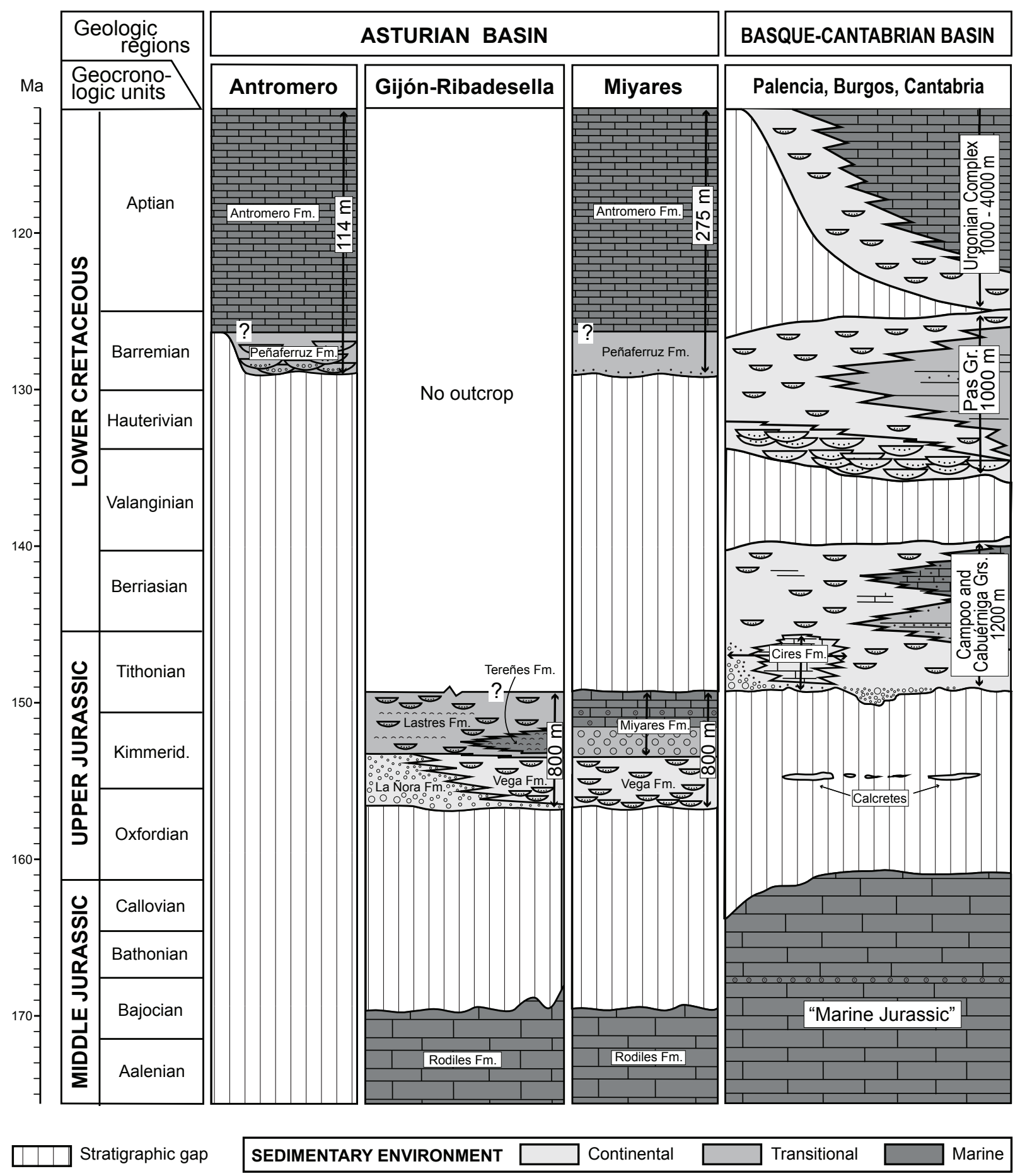

Fig. 5.- Chrono-lithostratigraphic chart for the Middle-Upper Jurassic and Lower Cretaceous (pre-Albian) deposits of the Asturian basin, and their correlation with the Basque-Cantabrian basin deposits. Timescale after Ogg et al.(2008). Modified from Pujalte et al.(2004). Indicated thickness of the Urgonian Complex comprises the total unit, Aptian plus Albian.

de Siero (González-Fernández et al., 2004). The Middle Unit consists of bioclastic limestones, with fragments of oysters and other indeterminate bivalves and orbitolinids (Palorbitolina). Quartz grains are abundant (Fig. 8B, C). In the type section this unit has been interpreted as a mixed siliciclastic- carbonate ramp (Alonso-García and Bahamonde, 2006) and the presence of abundant palorbitolines indicates an Upper Barremian-Lower Aptian age. The Upper Unit is represented by fine-to medium-grained calcareous sandstone. 

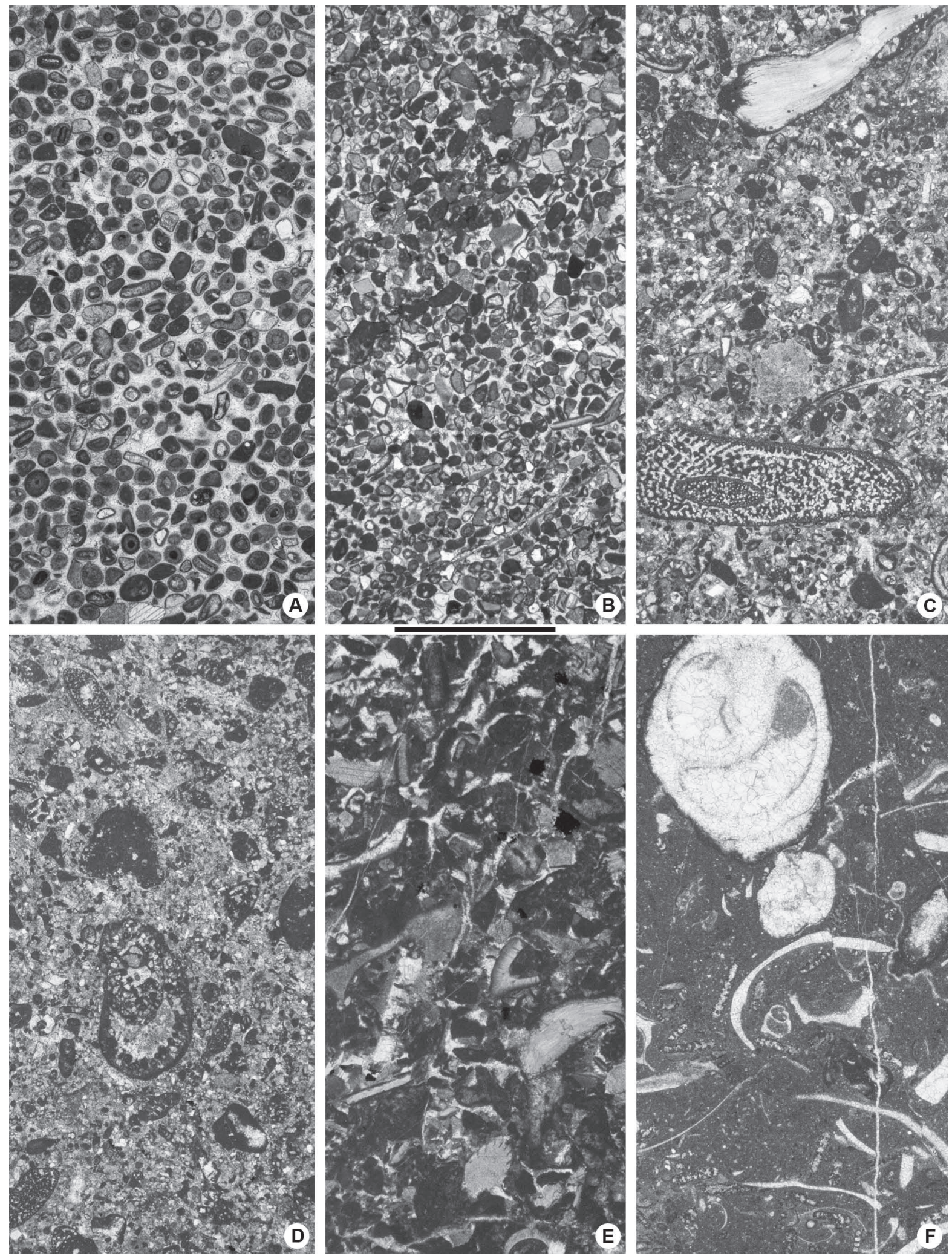

Fig. 6.- A. Homogeneous rounded to elliptic oolitic grainstone. The nuclei of the oolites can be formed by small foraminifera or Terquemella, MGB 59606 LP01. B. Grainstone constituted by rounded fragments of echinoderms and bivalves, pellets, and some oolites. Some fragments are micritized and the origin is uncertain. This microfacies contains also some grains of quartz, MGB 59537 LP01. C. Bioclastic packstone with dasyclads, larger foraminifera (A. lusitanica at the bottom of the figure), bivalve and echinoderm fragments, MGB 59535 LP01. D. Packstone with large foraminifera (A. lusitanica at the top and P. lituus in the middle of the figure) and fragments of bivalves and echinoids indicating a poorly washed, very shallow-water environment, MGB 59542 LP01. E. Packstone/grainstone with fragmented, densely packed bioclastats (bivalves, echinoids, bryozoans and "algae"), MGB 59543 LP01. F. Bioclastic wackestone with abundant gastropoda, bivalves and larger foraminifera (C. aff. tingitana), MGB 59563 LP01. Microfacies 8A-B from the Miyares Fm. (Middle Unit). Microfacies 8C-F from the Miyares Fm. (Upper Unit). Scale bar for all the microfacies is $2.4 \mathrm{~mm}$. 


\subsection{Collada de la Fumarea outcrop}

This outcrop is located $8 \mathrm{~km} \mathrm{NE}$ of Pola de Siero (Fig. 1). It corresponds to the outcrop previously described by Virgili et al.(1968) and Ramírez del Pozo (1969, named as "La Rimada"). The first authors describe 10-30 m of limestones, sandstones and marls with Cayeuxia and solenoporaceans on top of the La Nora Fm., suggesting a marine origin and an Upper Jurassic age for these sediments. In contrast, the second author describes $60 \mathrm{~m}$ of sandstones with two interbedded beds of algal limestones. He suggests a lacustrine environment for these sediments and a Kimmeridgian-Portlandian age. Our field observations indicate that only one level (2-3 m visible) of limestones is intercalated between the partially covered sandstones and clays. The two beds of algal limestones reported by Ramírez del Pozo (1969) are, in fact, a single bed duplicated by a fault. The calcareous interval consists of packstone-wackestones mainly comprising cyanobacterial structures, but no solenoporaceans have been identified. Therefore, based on our present data, the deposits of the Collada de la Fumarea outcrop are included in the Vega Fm., and are interpreted as deposited in a fluvial environment with occasional ponds (Fig. 2).

\subsection{El Ferradal outcrop}

Located $3 \mathrm{~km}$ NNE of Pola de Siero, this outcrop was mapped by Beroiz et al.(1973) within a terrigenous unit assigned to the Late Jurassic, and later named the Vega Fm. by Valenzuela et al.(1986). It is a small and discontinuous outcrop consisting of about $5 \mathrm{~m}$ of sandy and bioclastic limestones with foraminifera. Two different microfacies were recognized: a) packstone with abundant angular quartz grains, gyrogonites of charophytes, small miliolids, fragments of bivalves, bryozoans, echinoderms, gastropods (Fig. 8D) and rare Choffatella gr. decipiens; b) packstone with rare quartz grains and abundant foraminifera (Glomospira sp., Choffatella gr. decipiens, Andersenolina sp., Sabaudia minuta, Mayncina cf. cuvillieri, Novalesia sp., and large indeterminate agglutinates, Fig. 8E). The foraminiferal assemblage clearly indicates a marine environment and a BarremianAptian age. Therefore, the strata of the El Ferradal outcrop cannot be ascribed to the Vega Fm.; its foraminiferal content could instead be related to the foraminiferal assemblage observed in the lower part of the Antromero Fm.

\subsection{Pico San Martín outcrop}

This outcrop is located $8 \mathrm{~km}$ NNW of Pola de Siero (Fig. 1), being named "Santa Cecilia" by Ramírez del Pozo (1969). This author described here two successive stratigraphic intervals: a) $140 \mathrm{~m}$-thick of medium-grained sandstone alternating with red clays; b) 310 m-thick of sandy clays, sandstones and locally microcrystalline limestones with Girvanella, ostracods, bivalves and gastropods. Ramírez del Pozo (op. cit.)

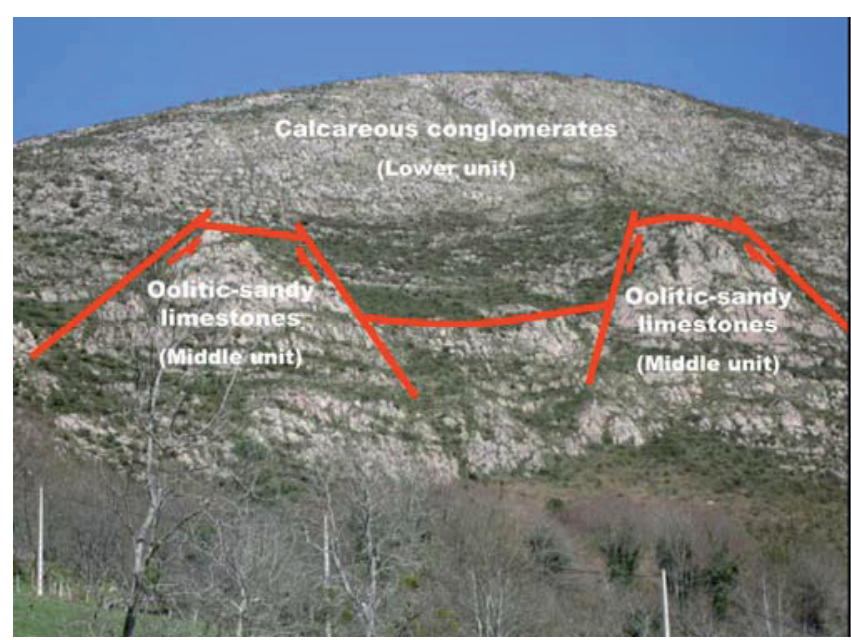

Fig. 7.- Synsedimentary faults in the contact between the Lower and Middle Units of Miyares Fm. (note the overturning of the sedimentary sequence). Their interpretation as synsedimentary faults is based on the differences of oolitic limestone thickness in the two hanging wall blocks with respect to the foot wall block.

correlated the lithologies of the lower interval with deposits of the present Vega Fm., while those of the upper interval were correlated with other deposits currently attributed to the Tereñes and Lastres Formations. Based on a study of the ostracod associations, the author attributed the entire section to the Kimmeridgian - Portlandian interval.

However, according to our field observations, the thickness of the Vega Fm., overlying the La Ñora Fm. in this section, does not exceed $150 \mathrm{~m}$, i.e. $100 \mathrm{~m}$ of a lower terrigenous interval and $50 \mathrm{~m}$ of a more calcareous upper interval. The lower interval can be clearly attributed to the Vega Fm., where it was assigned by Ramírez del Pozo (1969), but the attribution of the upper interval to the Tereñes and/or Lastres Formations is questionable. A correlation with the algal limestone of the Collada de la Fumarea outcrop is suggested. This upper interval should therefore also be included in the Vega Fm.

\section{Remarks on selected larger foraminifera}

The main characteristics of the selected genera and/or species of larger foraminera identified in the studied stratigraphic sections are presented and discussed in order to justify the generic and specific ascriptions. The biostratigraphic settings and ages reported for these taxa in the literature are also discussed. The taxa are figured at the standard magnifications to facilitate comparisons. The terminology used for the architectural and structural shell elements refers to Hottinger (2006).

Genus Anchispirocyclina JoRdAN AND APPLIN, 1952

(Type species: Dicyclina lusitanica EGGER, 1902)

Finely agglutinated, flat lenticular to discoidal shells with strong dimorphism. There is a planispiral involute mode of growth in the earlier stages, becoming peneropliform to reniform or cyclic in the adult stages. The numerous chambers 

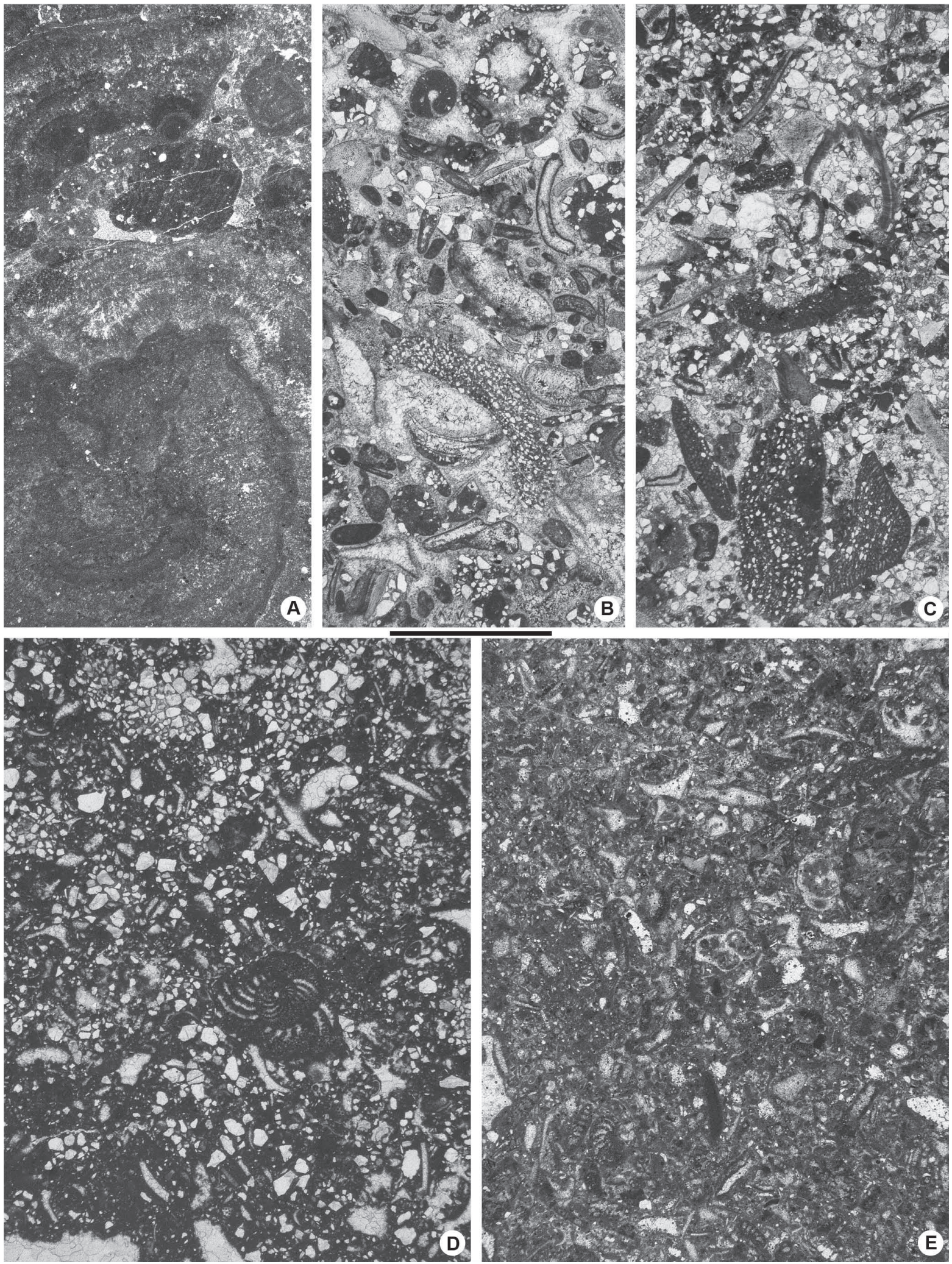

Fig. 8.- A. Wackestone with larger oncoids. Probably lacustrine environment, MGB 59540LP 01. B. Packstone with large fragments of bivalves, gastropod sections and large agglutinated foraminifera including simple forms and Palorbitolina. Quartz content is abundant, MGB 59541 LP 01. C. Bioclastic packstone with larger foraminifera mainly Palorbitolina and bivalves and angular quartz, MGB 59539 LP 01. D. Quartz-bearing packstone with some transported larger foraminifera (C. gr decipiens), MGB 59544 LP 01. E. Bioclastic packstone-wackestone with diverse fragmented organisms. Some of them appear micritized or sparitized, MGB 59555 LP 01. Microfacies 9A-C from the Antromero Formation in the Miyares section. Microfacies 9D-E, from Antromero Formation in the El Ferradal outcrop. Scale bar for all the microfacies is $2.4 \mathrm{~mm}$. 

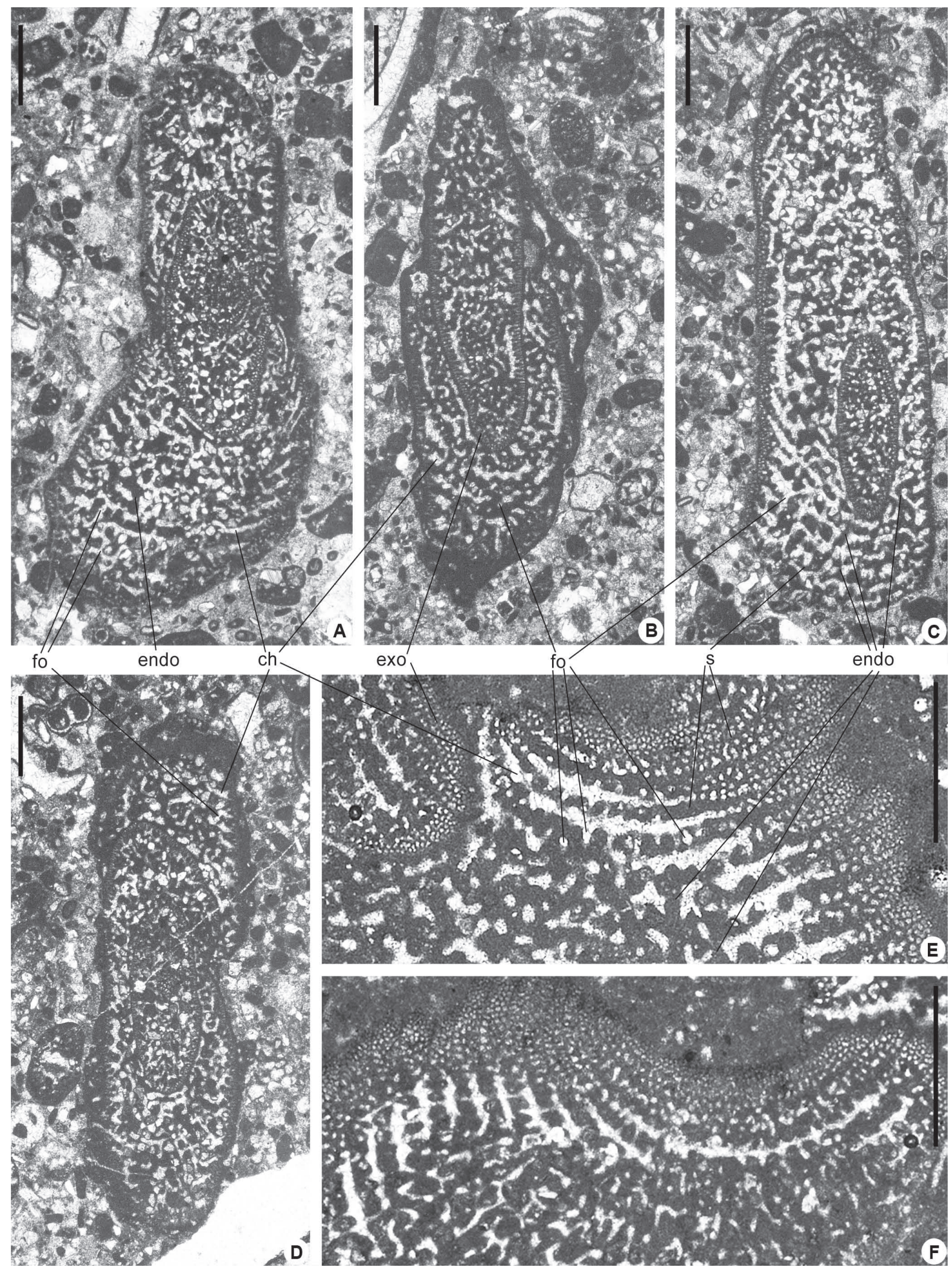

Fig. 9.- Megalospheric forms of Anchispirocyclina lusitanica: A-C, E-H, K-L, axial slightly oblique sections. A, MGB 59534 LP01.01; B, 59542 LP01.01; C, MGB 59542 LP01.02; E, MGB 59534 LP01.02; F, MGB 59542 LP01.05; G, MGB 59542 LP01.04; H, MGB 59542 LP02.01; K, MGB 59543 LP02.01; L, MGB 59543 LP04.01. D, I, equatorial sections. D, MGB 59542 LP 01.03; I, MGB 59543 LP 03.01. J, tangential section, MGB 59542 LP 02.02. M, slightly oblique section almost parallel to the equatorial plane, MGB 59534 LP 01.03. Note in all of the centred sections the large, spherical embryo with irregular outline due to the growth of sparite crystals. The two embryonic chambers, protoconch and deuteroconch cannot be observed. All the specimens from the Miyares Formation (Upper Unit). Scale bar is $0.6 \mathrm{~mm}$ for all microphotographs. 

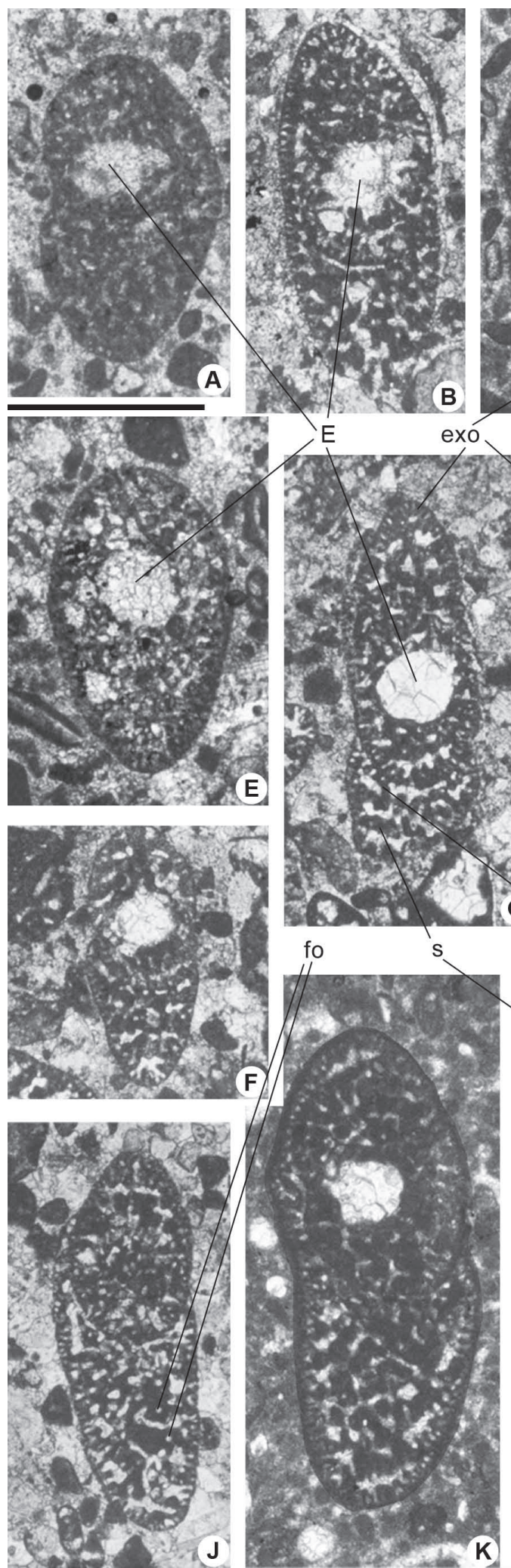

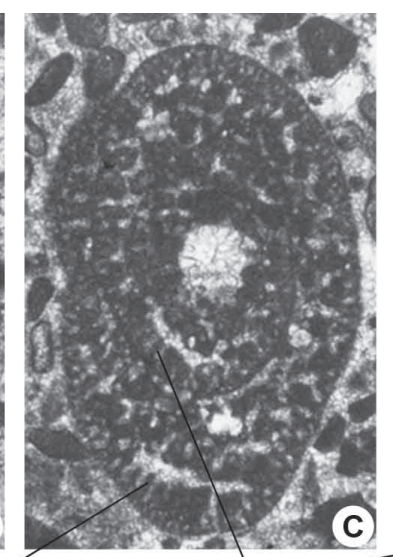

(C)

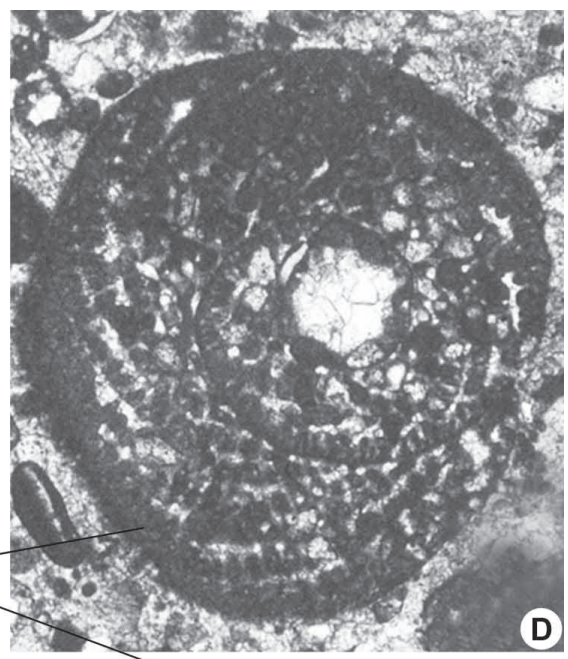

(D)
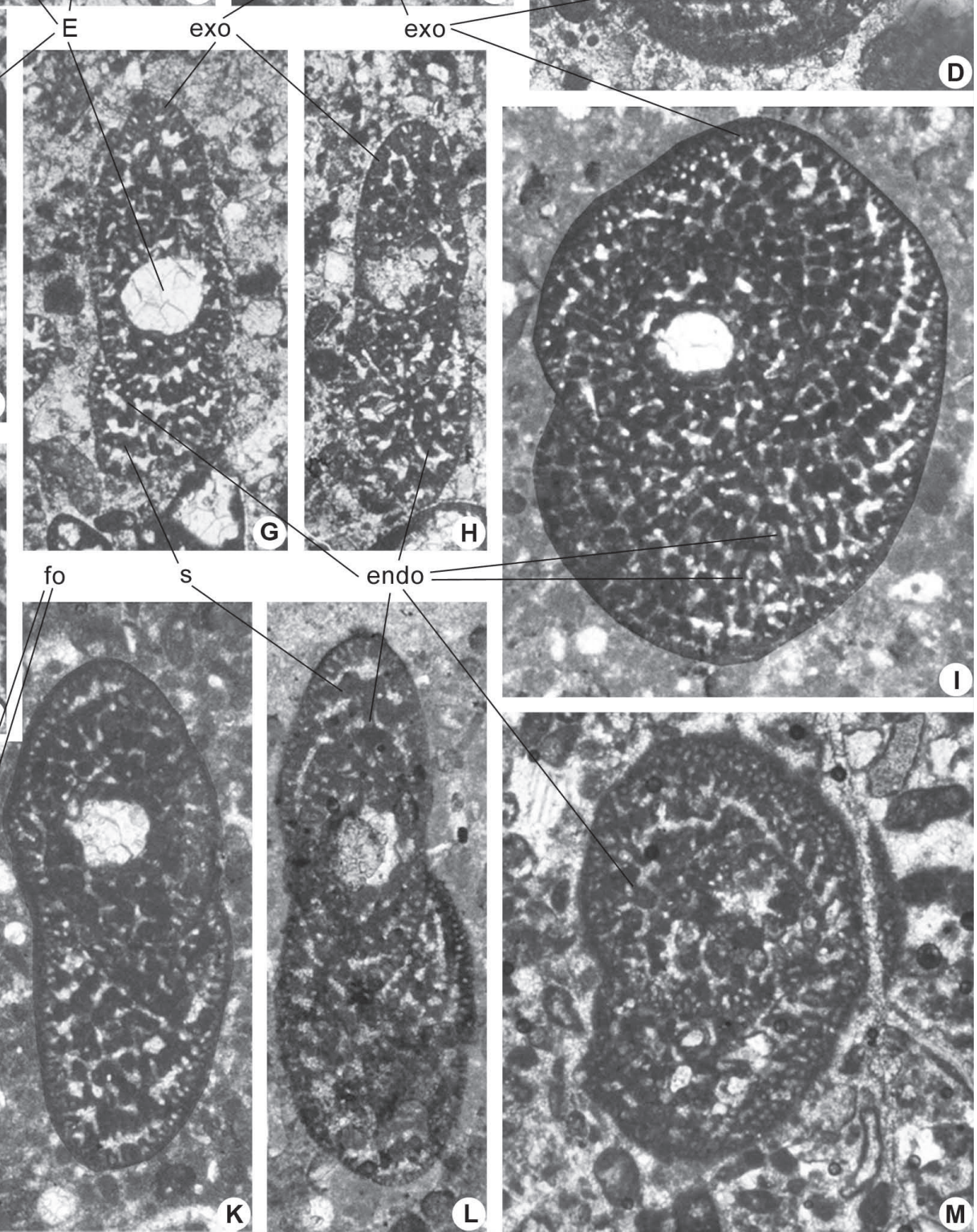

Fig. 10.- Microspheric forms of Anchispirocyclina lusitanica: A, D, subaxial slightly oblique sections, MGB 59535 LP01.01 and MGB 59535 LP01.04. B-C, tangential sections almost parallel to the axial plane, MGB 59535 LP01.02 and MGB 59535 LP01.03. E-F. Tangential sections showing the small alveols of the dense polygonal subepidermal network, MGB 59543 LP04.02 and MGB 59543 LP04.03. All the specimens from Upper Miyares (Upper Unit). Scale bar is $0.6 \mathrm{~mm}$. 
are broad and low. The marginal part of the chamber lumina is occupied by exoskeletal elements consisting of several series of fine beams and rafters forming a dense polygonal subepidermal network. The inner part of the chambers is occupied by endoskeletal elements consisting of radial pillars aligned from one chamber to the next, but alternating in position in successive stolon planes. The successive septa are joined by multiple foramina. The genus Anchispirocyclina is reported to be from the Late Jurassic to lowermost Early Cretaceous (Loeblich and Tappan, 1987).

\section{Anchispirocyclina lusitanica (EGGER, 1902)}

(Fig 9A-M, Fig. 10A-E)

The first description of A. lusitanica was given by Egger (1902) on the basis of specimens collected by Choffat from the uppermost Jurassic sediments of Cape Espichel in Portugal (Choffat, 1887). For details about the successive generic ascriptions and synonymies of this species, see Maync (1959). Maync ascribes A. lusitanica to lower Kimmeridgianlower Valanginian age. It is important to mention some later works that followed the exhaustive Maync's study (1959). Hottinger (1967) describes two subspecies from Morocco: A. lusitanica minor and A. lusitanica lusitanica, indicating an early to middle Kimmeridgian age for the former and a late Kimmeridgian-Portlandian age for the latter. Ramalho (1971), in a study of the neighbourhood of Lisbon (including the type-locality), mentioned $A$. lusitanica associated with $E$. virguliana and $R$. chouberti in shallow to restricted marine sediments that were attributed, respectively, to the Portlandian B and to the Purbeckian. No mention of Anchispirocyclina from the Valanginian beds. Galbrun et al. (1990) identify $A$. lusitanica in the Portuguese locality of Bias do Norte from sediments corresponding to the Chron M18 and M18n.

The Asturian specimens attributed to $A$. lusitanica display typical anchispirocyclinid characteristics, but differ from isolated specimens collected for comparison in the Lagosteiros beach (type-locality of $A$. lusitanica) because they do not reach the cyclic final growth stage, either in A- or B-forms. The same characteristic is also reported by Hottinger (1967) for the Moroccan specimens, which are smaller than the Portuguese specimens. It is currently unknown whether this difference is of biostratigraphical value or not.

In the northern Spain, A. lusitanica has previously been mentioned as occurring at Ramales (Santander) by Rat (1959) "in a level which is believed to represent either Upper Portlandian or basal Valanginian" (Maync 1959; nevertheless, it is noted that, in the 1950s, some authors did not consider the Berriasian as representing a distinct stage between the Portlandian and Valanginian). Ramírez del Pozo (1971) reports A. lusitanica from three localities in the NW of the Iberian Peninsula: Ramales (Santander), Ordejón (Burgos) and Larreitxiqui (Basque country), suggesting a Berriasian age for all of them. In the studied outcrops, $A$. lusitanica has been found only in the Miyares Fm. (Upper Unit).
Genus Pseudocyclammina Yabe AND Hanzawa, 1926

(Type species: Cyclammina lituus Yoконама, 1890)

Agglutinated, lobulate sub-cylindrical shells, with an exoskeleton composed of different elements, beams and rafters, resulting in a polygonal subepidermal network. The genus Pseudocyclammina does not present endoskeletal elements within the chamber lumina. The chambers are planispirally disposed, but may uncoil in the final stages of growth. The nepionic stages of the B- form are streptospiral, while those of the A-form may be either planspiral or streptospirally arranged. The massive septa are pierced by large rounded openings, which are disposed in a cribate system occupying almost the entire apertural face. Loeblich and Tappan (1987) report the genus Pseudocyclammina to be from the Early Jurassic (Liassic) to the Coniacian. In the Pyrenean basin the genus is recorded in the Santonian (Boix et al., 2011).

\section{Pseudocyclammina gr. lituus (Yоконама, 1980)}

(Fig. 11A-I)

The Asturian specimens attributed to the genus Pseudocyclammina have a cylindrical to subglobular shape, with hemispheric to globular chambers arranged in two (exceptionally three) streptospiral to planspiral whorls. No final uncoiling stage is present. The exoskeletal elements are thick, deep and widely spaced. Such characteristics may associate the Asturian specimens with either P. lituus or P. sphaeroidalis. However, after comparing our material with the topotypes of $P$. lituus the studied specimens may correspond to juvenile forms of this species (with only 1.5 to 2 whorls), and not to the adult forms of $P$. sphaeroidalis (see figs. 14-17 in Hottinger, 1967). Hottinger (1967) considers the two species to be successive in time in Morocco: P. sphaeroidalis would have occurred in the Kimmeridgian, whereas $P$. lituus would characterize the Portlandian. Ramalho (1971) indicates the presence of P. lituus in Portlandian to Valanginian rocks from Portugal. Bassoulet (1997) reports $P$. gr. lituus to be from the Late Oxfordian to Berriasian, and probably the Valanginian.

In the Asturian successions, $P$. gr. lituus is present in the Upper Unit of the Miyares Fm. associated with A. lusitanica. The only earlier record of $P$. lituus from Asturias is from España Beach (Ramírez del Pozo, 1969).

\section{Genus Choffatella Schlumberger, 1905}

(Type species: Choffatella decipiens SCHLUMBERGER, 1905)

Finely agglutinated, flat planispiral involute (some morphotypes tend to uncoil) shells with an exoskeleton forming a polygonal subepidermal network. No endoskeletal elements are present. Choffatella differs from Pseudocyclammina in having massive septa pierced by numerous openings and placed in an elongated depression in the median plane of the shell. The foraminal axes are continuous from one chamber to the next.

The genus Choffatella has been recorded from the Oxfordian to the Cenomanian (Loeblich and Tappan, 1987). 

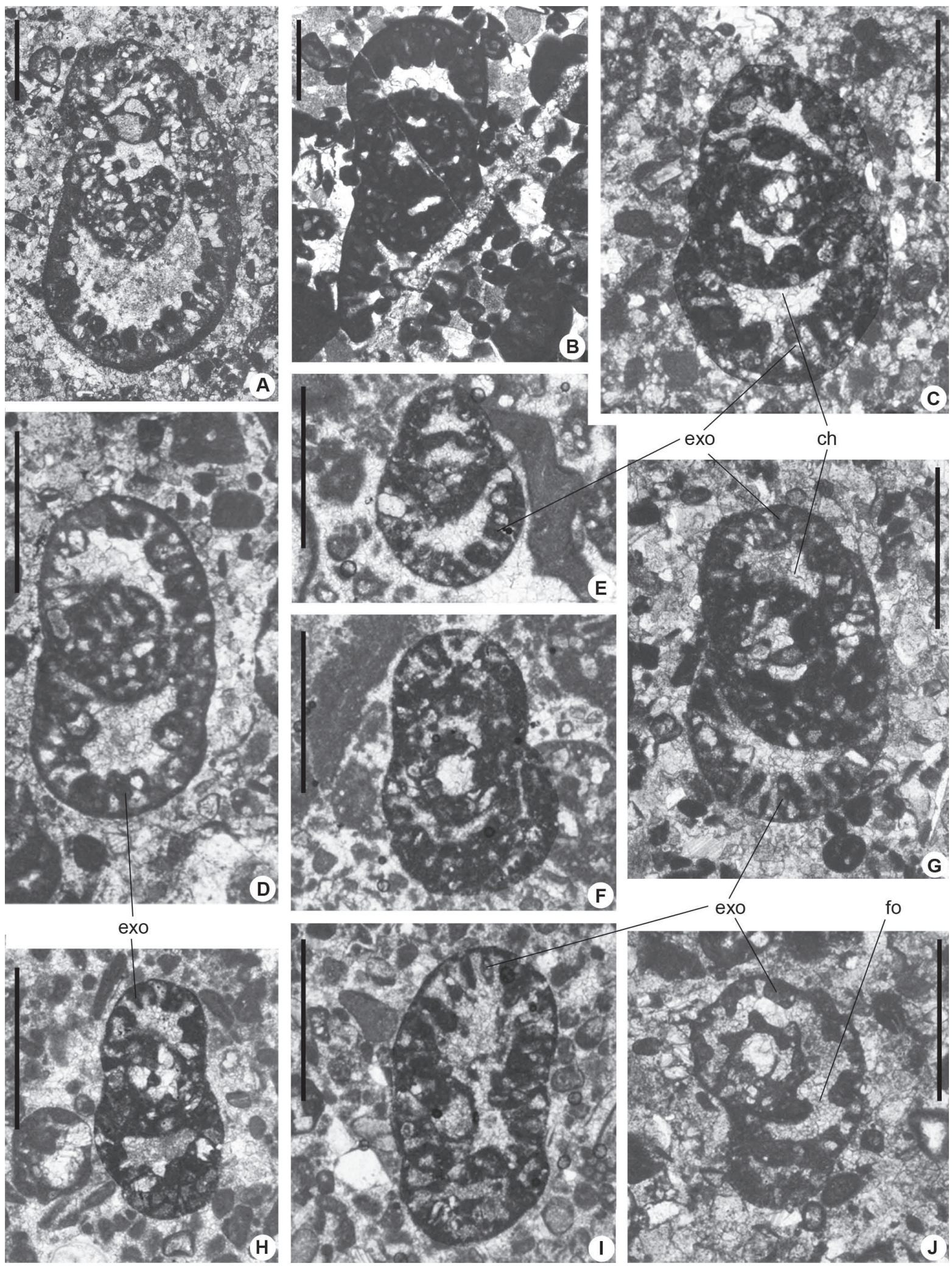

Fig. 11.- Pseudocyclammina lituus: A, D-E, tangential sections parallel to the axial plane, MGB 59542 LP01.05, MGB 59542 LP01.06 and MGB 59534 LP01.04. B, axial section, MGB 59538 LP01.01. C, F-G, slightly oblique section very close to the axial plane, MGB 59542 LP03.01, MGB 59534 LP01.05 and MGB 59542 LP04.01. H, subaxial section, MGB 59534 LP01.06. I. Oblique section, MGB 59534 LP01.07. J, Everticyclammina virguliana: equatorial section showing the large single foramen, and the quadrangular outlined exoskeleton alveols, MGB 59542 LP02.03. All the specimens are megalospheric forms. All the specimens from Miyares Formation (Upper Unit). Scale bar is $0.6 \mathrm{~mm}$. 

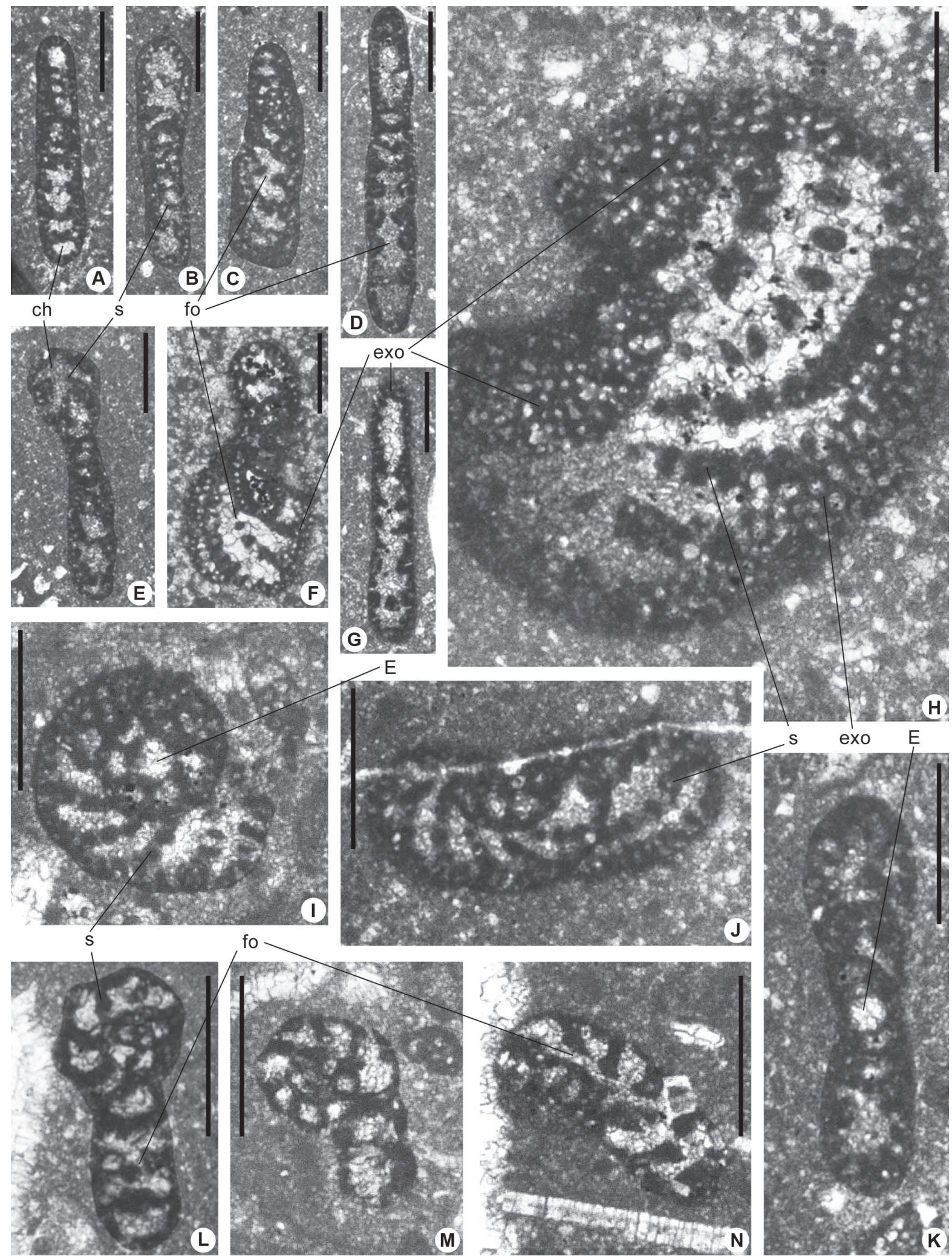

G

$E$
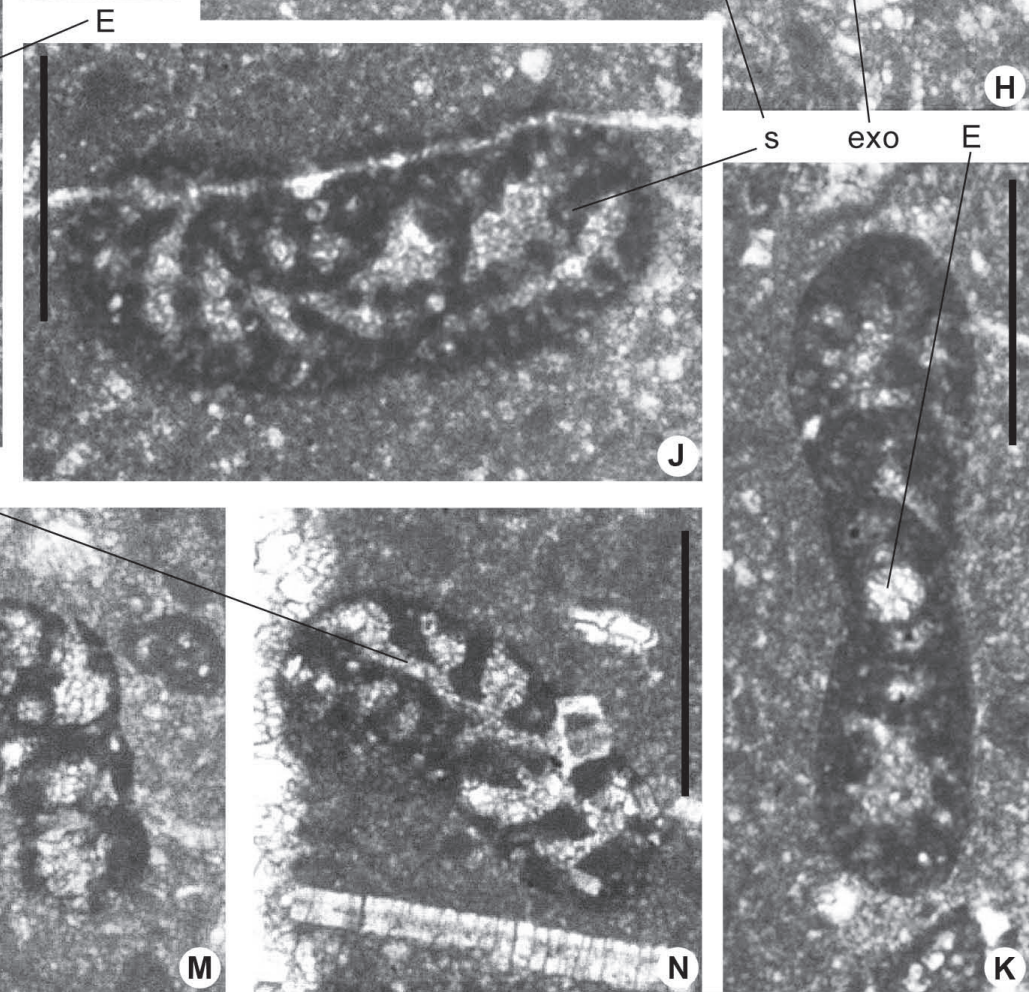

Fig. 12.- Choffatella cf. tingitana A-B, E, oblique, non centred section, MGB 59536 LP01.01, MGB 59536 LP01.02 and MGB 59536 LP01.06. C, oblique section, MGB 59536 LP01.03. D, G, tangential sections, MGB 59536 LP01.04 and MGB 59536 LP01.08. F, oblique, non centered section, MGB 59536 LP01.07. H, tangential section showing the exoskeleton and septa with their multiple foramina, MGB 59536 LP01.05. I, equatorial, slightly oblique section of a megalospheric specimen, MGB 59536 LP01.09. J. oblique section, MGB 59536 LP01.10. K, axial section of a megalospheric form, MGB 59536 LP01.14. L-N. Feurtillia frequens: L-M, equatorial sections, MGB 59536 LP01.11 and MGB 59536 LP01.12. N, oblique section, MGB 59536 LP01.13. Note that most of the figured specimens (except I, J and K) are not centred and they can be either macrospheric or microspheric foms. All the specimens from Miyares Fm. (Upper Unit). Scale bar is $0.3 \mathrm{~mm}$. 


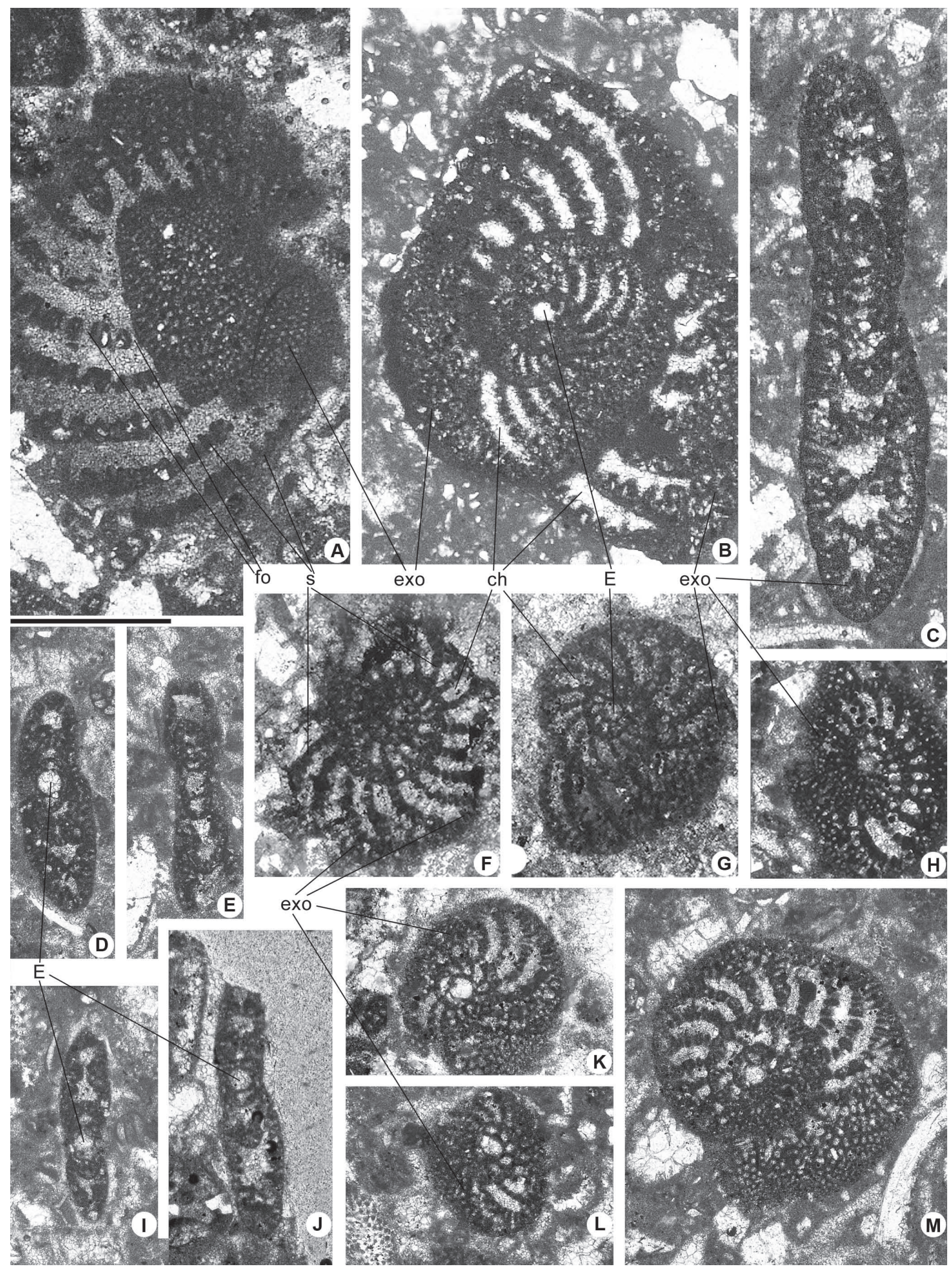

Fig. 13.- Choffatella gr. decipiens: A, tangential section of a microspheric? specimen, MGB 59555 LP03.01. B, F-H, K-M, equatorial slightly oblique sections of megalospheric specimens, MGB 59544 LP01.01, MGB 59604 LP01.01, MGB 59604 LP01.02, MGB 59603 LP01.01. C, subaxial section of a megalospheric(?) form, MGB 59555 LP01.01. D-E, I-J, axial, slightly oblique sections of macrospheric forms, MGB 59555 LP05.01, MGB 59555 LP02.01, MGB 59555 LP01.02 and MGB 59555 LP02.03. All the specimens from the Antromero Fm.: A-C, D-E and I-M from El Ferradal outcrop; F-H from Venta del Jamón. Scale bar is $0.6 \mathrm{~mm}$. 


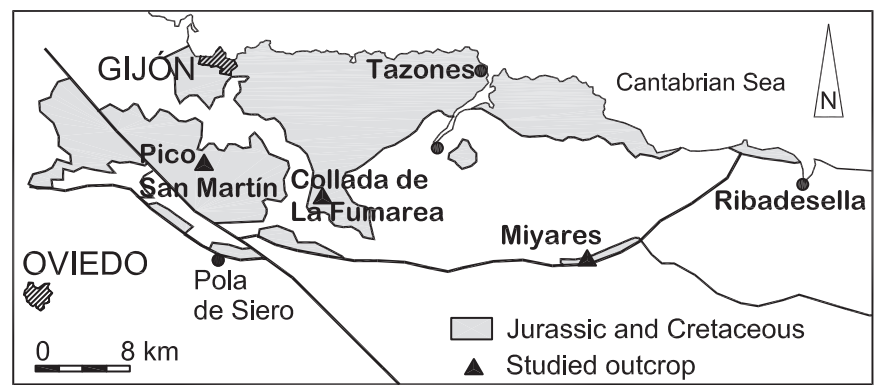

Tazones - Ribadesella

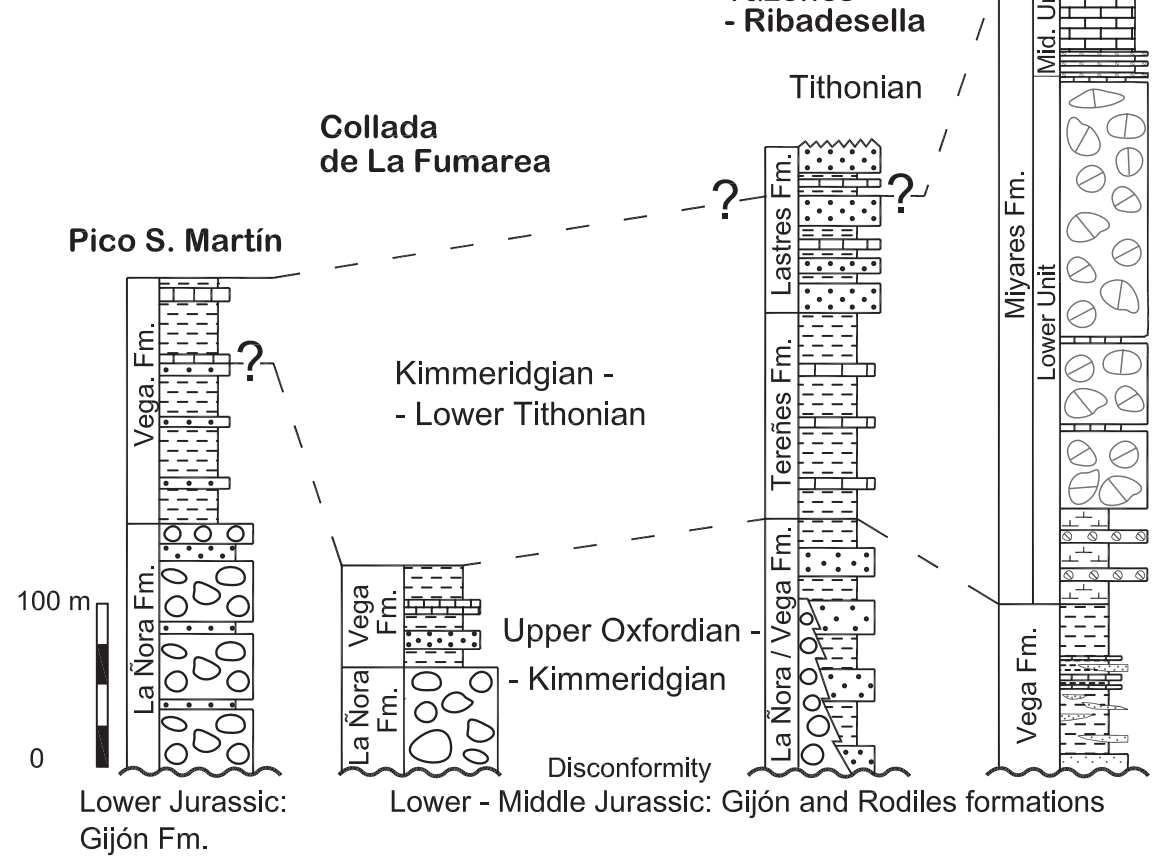

Fig. 14.- Scheme of correlation of the Upper Jurassic sedimentary sequences in the studied outcrops, with addition of the Tazones-Ribadesella reference section, based on data from Valenzuela et al.(1986).
Choffatella cf. tingitana HotTINGER, 1967 (Fig. 12A-K)

This small-sized Choffatella is attributed to $C$. gr. tingitana due to its size (the specimens do not exceed $1.5 \mathrm{~mm}$ ) and the regularity of the spire. The early chambers are quadrangular, tending to elongate in the adult stages. Unlike the Moroccan specimens, morphotypes that do not uncoil were observed in our samples. The number of chambers in the first whorl is about $6-7$, increasing to $14-15$ in the second whorl. All the specimens found have only two or two-and-a-half whorls of spire. Some sections prepared from well-preserved topotypes of $C$. tingitana, provided to us by Prof. Lukas Hottinger (Basel), show mainly two-and-a-half to three spire whorls in A-forms and three-and-a-half to four in B-forms. All of the measured specimens from Asturias are A-forms. No B-form has been clearly identified. C. tingitana has been reported to be from the Kimmeridgian-Portlandian of Morocco (Hottinger, 1967). C. cf. tingitana related to the Asturian successions has been found only in the restricted facies of the Upper Unit of the Miyares Fm. associated with Feurtillia frequens and rare $A$. lusitanica.

\section{Choffatella gr. decipiens SCHLumberger, 1905}

For further information about the characteristics of this species see Maync (1949). It is a cosmopolite species characterizing Hauterivian?-“Gargasian” shallow water deposits
(Jaffrezo, 1980). Ramírez del Pozo (1971) reports C. decipiens associated with Palorbitolina lenticularis in sediments from northern Spain, which were attributed to the lower Aptian (Bedulian). All our specimens attributed to $C$. gr. decipiens were originated from sedimentary successions ascribed to the Antromero Fm., where a great variation of sizes and morphologies was observed. This variation occurs within the same sample and/or between samples; in the former case, the co-existence of two A-forms (A1 and A2) and only one Bform had to be accepted (Sigal, 1959) but, in the latter case, two or more different species could be separated, as suggested by Arnaud-Vanneau (1980), Cherchi and Schroeder (1981), and Neagu and Cîrnaru (2004). Unfortunately, the paper by Neagu and Cîrnaru (2004) only shows the external view of the specimens, which does not enable an appreciation of the differences between species. The poor material from Asturias prevents this kind of work from being undertaken. The specimens from the El Ferradal outcrop (Fig. 13D, E, I-M) show small, flat shells with two-and-a-half to three (only one section shows four) spiral whorls in A-forms. The few centred equatorial sections show very small proloculi. Exceptionally, a large specimen (Fig. 13B) seems also to be an A-form. No specimens identified as B-forms (Fig. 13A, C) are centred, and therefore their attribution is doubtful. The specimens from El Ferradal are comparable with specimens 
from the "Venta del Jamón" (Fig. 13F-H), which were studied for comparison. In both localities, El Ferradal and Venta del Jamón (see location in Fig. 1), these small C. gr. decipiens are associated with Glomospira, Andersenolina sp., Sabaudia minuta, Mayncina cf. cuvillieri and Novalesia sp. Palorbitolina lenticularis was not found.

Genus Feurtillia MAYNC, 1958

(Type species: Feurtillia frequens MaYNC, 1958)

Agglutinated, planispiral to uncoiled, laterally compressed shells. The septa are thick, and the apertural face is narrow. It has only one large and elongate aperture placed in the median plan of the shell. The genus Feurtillia, with no endoskeleton has an exoskeleton forming a perfectly differentiated polygonal subepidermal network. For more details about the characteristics of the genus, see Maync (1958). The age attributed to Feurtillia is Late Jurassic-Early Cretaceous (Berriasian to Valanginian) (Loeblich and Tappan, 1987).

\section{Feurtillia frequens MAYNC, 1958 \\ (Fig. 12L-N)}

For further information about the characteristics of this species, see Maync (1958). F. frequens is not abundant in the studied material and appears to be associated with $C$. cf. tingitana and rare A. lusitanica only in the uppermost part of the Miyares Fm. The specimens found in the Asturian materials have the same characteristics as F. frequens from the locality type (Feurtille, Jura, Switzerland). The equatorial sections show two-and-a-half or three whorls of chambers planspirally arranged followed by two to five uncoiled chambers. The axial sections are flat, and allow the septum traversed by the foramen to be observed.

Maync (1958) attributes this species to a Purbeckian age. Fourcade (1970) reports this species to be from the Kimmeridgian in Southern Spain, while Ramalho (1971) found Feurtillia in Portugal, suggesting an Portlandian-Valanginian age. Bassoullet (1997) agrees with a Tithonian-Valanginian range.

Genus Everticyclammina ReDmond, 1964

(Type species: Everticyclammina hensoni REDMOND, 1964)

Agglutinated, bilaterally compressed shell. The chambers of the initial stages of growth are planspiral involute arranged, but become uncoiled in the adult stages. The successive chambers are joined by means of a large foramen placed in the centre of the septum. Everticyclammina can be easily differentiated from the genera described above by its alveolar exoskeleton composed of undifferentiated beams and rafters forming a layer of undivided alveoli. Loeblich and Tappan (1987) reported for this genus an Upper Oxfordian-Cenomanian age, while Fugagnoli (2000) placed its appearance in the Late Sinemurian-Domerian.

\section{Everticyclammina virguliana (KoECHLIN, 1942)}

(Fig. 11J)
This species is characterized by a weak dimorphism: the Bforms have two-and-a-half spiral whorls with 9-11 chambers in the last whorl, while the A-forms have one to two whorls of planispirally arranged chambers, with 6-8 chambers in the last whorl. The uniserial stage of growth can be much more developed in B- than in A-forms. The massive and backcurved septa are perforated by a median, large and almost circular opening. The characteristics of the specimens found in the studied materials coincide with the description given by Koechlin (1942) for "Pseudocyclammina" virguliana. All the Asturian specimens belong to the A-forms; no B-form has been found. They are not frequent but are easily identifiable. They appear in the same samples as Anchispirocyclina lusitanica and Pseudocyclammina gr. lituus.

Hottinger (1967) reports this species to be from the Kimmeridgian and Portlandian of Morocco. Ramalho (1971) indicates that $E$. virguliana is already present in the upper Kimmeridgian of Portugal, but is more abundant in the Portlandian and Purbeckian stages. The specimens studied by Ramalho (plate 18 figs. 6 and 8) are bigger than our specimens but have the same specific characteristics.

\section{Geological evolution of the Asturian Basin}

The detailed geological map of the Jurassic and pre-Albian Cretaceous sucessions, the new studies of the outcrops of central and eastern Asturias and their stratigraphic correlation with the well-known rocks outcropping on the coast (Fig. 14), allowed some aspects of the main geological events influencing the sedimentation in the Asturian Basin during the Late Jurassic and Early Cretaceous to be clarified.

After the marine carbonate sedimentation represented by the Lower to Middle Jurassic Gijón and Rodiles Formations, the region emerged as a result of tectonic extensional movements (Aurell et al., 2002), which could be interpreted as equivalents to the second stage of rifting of Mas et al.(2004), resulting in the erosion of these formations with a marked palaeorelief. Continental deposits of the La Nora and Vega Formations were then deposited.

A transgressive event occurred during the KimmeridgianTithonian interval. In the north (coastal outcrops in the Tazones-Ribadesella area, Fig. 1), this transgression was responsible for the sedimentation of the shallow marine-to-littoral Tereñes and Lastres Formations, while to the south-west (Pico San Martín and Collada de la Fumarea outcrops) the mostly fluvial sediments of the Vega continued to be deposited. At the same time, to the south-east (Miyares outcrop) the deposits representing the Miyares Fm. were sedimented in a tectonic trough opened to the north. This trough probably originated as a result of the conjugate normal faults associated with the Llanera Fault, which are in turn related to the climax stage of the Bay of Biscay Rift.

The Tithonian larger foraminifera assemblage identified in the shallow-water carbonate facies of the Asturian Basin is similar to those recorded in other peri-Tethyan basins (e. g. 
Hottinger, 1967; Ramalho, 1971; Aurell et al., 1994; Whittaker et al., 1998; Aurell et al., 2002; Ornelas and Hottinger, 2006 among others)

The Jurassic deposits were probably followed by a period of no deposition and/or erosion that ranges from the latest Tithonian to earliest Barremian. The first Cretaceous deposits recognized in the studied area are from the Lower Barremian, and are represented by the continental Peñaferruz Fm. During the Upper Barremian-Aptian interval, a new marine transgression flooded the NW of the Iberian Peninsula and, in the Asturian Basin, resulted in the deposition of the Antromero Fm.

\section{Conclusions}

Several Upper Jurassic and Lower Cretaceous outcrops previously assigned to other ages have been identified in central and eastern Asturias, and a new formation, the Miyares Fm., has been described. The Miyares Fm. conformably overlies the Vega Fm., and has been subdivided into three successive units. The Lower Unit consists of calcareous conglomerates deposited in a fan delta environment, the Middle Unit is formed by oolitic limestones deposited in a marine high-energy environment and the Upper Unit consists of bioclastic limestones deposited in a marine shallow-to-restricted environment. The Miyares Fm. is correlated with the Tereñes and Lastres Formations and it is interpreted as deposited in a tectonic trough opened to the north. The origin of this trough is probably related to the extensional faulting processes (Llanera Fault) previous to the opening of the Bay of Biscay and coinciding with the second stage of mesozoic iberian rift.

The Upper Unit of the Miyares Fm. yields a rich assemblage of agglutinated larger foraminifera, which have been identified for the first time in Asturias successions. The foraminiferal assemblage is dominated by Anchispirocyclina lusitanica associated with Pseudocyclammina lituus, Everticyclammina virguliana, Choffatella aff. tingitana and Feurtillia frequens, suggesting a Tithonian age. This assemblage is similar to those described in other basins of the peri-Tethys.

Cretaceous deposits overlie the Miyares Fm. The fossiliferous content indicates a Lower Barremian-Aptian age.

\section{Acknowledgements}

This work has been funded by the research project CN-08030 from the Instituto Geológico y Minero de España, and partially by the project CGL2009-08371 from the Ministerio de Ciencia e Innovación. We would like to extend our thanks to Jose Carlos Garcia-Ramos from the Museo del Jurásico de Asturias (MUJA) for the comments and suggestions made. We are also very grateful to J. Pignatti from "La Sapienza" University (Roma) and the two reviewers, Ramón Mas from the Complutense University (Madrid) and Davide Bassi from Ferrara University, for their useful comments.

\section{References}

Alonso, J. L., Pulgar, J. A. (1995): La estructura de la Zona Cantábrica. In: C. Aramburu, F. Bastida, (eds.), Geología de Asturias. Trea, Gijón, pp. 103-112.

Alonso, J. L., Pulgar, J. A., García-Ramos, J. C., Barba, P. (1996): Tertiary Basins and Alpine Tectonics in the Cantabrian Mountains (NW Spain). In: P.F. Friend, C.J. Dabrío, (eds.), Tertiary basins of Spain: The Stratigraphic Record of Crustal Kinematics. Cambridge University Press, Cambridge, pp. 214-227.

Alonso-García, M., Bahamonde, J.R. (2006): Sedimentología y caracterización paleoambiental de la serie cretácica inferior de AntromeroLuanco (Asturias). Geogaceta 40, 247-250.

Arnaud-Vanneau, A. (1980): Micropaléontologie, paléoécologie et sédimentologie d'une plate-forme carbonatée de la marge passive de la Téthys: L'Urgonien du Vercors septentrional et de la Chartreuse (Alpes occidentales). Géologie Alpine 11, 1-874.

Aurell, M., Mas, R., Meléndez, A., Salas, R. (1994): El tránsito JurásicoCretácico en la Cordillera Ibérica: relación tectónica-sedimentación y evolución paleogeográfica. Cuadernos de Geología Ibérica 18, 369-396.

Aurell, M., Meléndez, G.,Olóriz, F., Bádenas, B., Caracuel, J., GarcíaRamos, J.C., Goy, A., Linares, A., Quesada, S., Robles, S., RodríguezTovar, F.J., Rosales, I., Sandoval, J., Suárez de Centi, C., Tavera, J.M., Valenzuela, M. (2002): Jurassic. In: W, Gibbons, T. Moreno (eds.), The Geology of Spain. Geological Society, London, pp. 213-254.

Aurell, M., Robles, S., Bádenas, B., Rosales, I., Quesada, S., Meléndez, G., García-Ramos, J.C. (2003): Transgressive-regressive cycles and Jurassic palaeogeography of northeast Iberia. Sedimentary Geology 162, 239-271. doi: 10.1016/S0037-0738(03)00154-4.

Barrón, E., Gómez, J.J., Goy, A. (2002): Los materiales del tránsito Triásico-Jurásico en la región de Villaviciosa (Asturias, España). Caracterización palinológica. Geogaceta 31, 197-200.

Barrón, E., Gómez, J.J., Goy, A., Pieren, A.P. (2006): The TriassicJurassic boundary in Asturias (northern Spain): Palynological characterisation and facies. Review of Palaeobotany and Palynology 138, 187-208. doi: 10.1016/j.revpalbo.2006.01.002.

Bassoullet, J. P. (1997): Les grands foraminifères. In: E. Cariou, P. Hantzperque (coords). Biostratigraphie du Jurassique ouest-européen et méditerranéen. Bulletin Centre Recherche Elf ExplorationProduction, Mémoire 17, 293-304.

Beroiz, C., Barón, A., Ramírez del Pozo, J., Gianini, G., Gervilla, M. (1973): Hoja geológica núm. 30 (Villaviciosa). Mapa Geológico de España E. 1:50.000. Segunda serie. I.G.M.E. Madrid.

Beroiz, C., Pignatelli, R., Felgueroso, C., Ramírez Del Pozo, J., Giannini, G., Gervilla, M. (1973): Hoja geológica núm. 29 (Oviedo). Mapa Geológico de España E. 1:50.000. Segunda serie. I.G.M.E. Madrid.

Boix, C., Frijia, G., Vicedo, V., Bernaus, J.M., Di Lucia, M., Parente, M., Caus, E. (2011): Larger foraminifera distribution and strontium isotope stratigraphy of the La Cova limestones (Coniacian-Santonian, "Serra del Montsec", Pyrenees, NE Spain). Cretaceous Research 32, 806-822. doi: 10.1016/j.cretres.2011.05.009.

Cherchi, A., Schroeder, R. (1981): Operculina cruciensis Pictet \& Renevier, 1858 (Foram.), une choffatelle oublié. Archives Sciences Geneve $34(2), 137$.

Choffat, P. (1887): Recherches sur les térrains secondaries au sud de sado, Portugal. Communicaçoes da Comissao dos trabalhos Geológicos de Portugal 1 (2), 222-311.

Cope, J.C. W. (2008): Drawing the line: the history of the Jurassic-Cretaceous Boundary. Proceedings of the Geologists' Association 119 , 105-117. doi: 10.1016/S0016-7878(08)80262-3.

Dubar, G., Mouterde, R. (1957): Extensión del Kimmeridgiense marino en Asturias desde Ribadesella a Gijón. Notas y Comunicaciones del 
Instituto Geológico y Minero de España 46, 209-215.

Dubar, G., Mouterde, R., Virgili, C., Suárez, L.C. (1971): El Jurásico de Asturias (Norte de España). Cuadernos de Geología Ibérica 2, 561580.

Egger, J., G. (1902): Der Bau der Orbitolinen und verwandter Formen. Abhandlungen der königlich bayerischen Akademie der Wissenschaften. Mathematisch-Physikalische Classe 21 (3), 577-600.

Fourcade, E. (1970): Le Jurassique et le Crétacé aux confins des chaines bétiques et ibériques (Sud-Est de l'Espagne). PhD Faculté de Sciences de Paris, $427 \mathrm{p}$.

García-Ramos, J.C., Valenzuela, M., Aramburu, C. (1979): Descripción e interpretación de ciclos fluviales en el Jurásico de Asturias. Cuadernos de Geología Ibérica 10, 23-33.

Galbrun, B., Berthou, P., Moussin, C., Azéma, J. (1990): Magnétostratigraphie de la limite Jurassique-crétacé en faciès de plate-forme carbonatée: la coupe de bias do Norte (Algarve, Portugal). Bulletin de la Société géologique de France (8 ${ }^{\mathrm{e}}$ série), 4 (1), 133-143.

González-Fernández, B., Menéndez-Casares, E., Gutiérrez-Claverol, M., García-Ramos, J. C. (2004): Litoestratigrafía del sector occidental de la cuenca cretácica de Asturias. Trabajos de Geología 24, 43-80.

Gradstein, F. M., Ogg, J. G., Smith, A. G. (2004): A Geologic Time Scale. Cambridge University Press, Cambridge, 589 p.

Gradstein, F. M., Ogg, J. G., Smith, A. G., Ogg, G. M., (2012): The Geologic Time Scale 2012. Elsevier, 1144 p.

Hottinger, L. (1967): Foraminifères imperforés du Mésozoique marocain. Notes et Mémoires du Service Géologique du Maroc 209, 168 p.

Hottinger, L. (2006): Illustrated glossary of terms used in foraminiferal research. Notebooks on Geology 2, 1-126. http://paleopolis.rediris.es/ cg/CG2006_M02/index.html.

Jaffrezo, M. (1980): Les formations carbonatées des Corbières (France) du Dogger à l'Aptien: Micropaléontogie stratigraphique, biozonation, paléoécologie. Extension des resultats à la Mésogée. $\mathrm{PhD}$ thesis, Université Pierre-et-Marie Curie, Paris, 614 p.

Karrenberg, H. (1934): Die postvariscische Entwicklung des Kantabroasturischen Gebirges (Nordwestspanien): Beiträge zur Geologie der westlichen Mediterrangebiete. Abhandlungen der Gesellschaft der Wissenschaften in Göttingen, Mathematisch-Physikalische Klasse (Folge 3) 11, 1491-1593. (Transl.: La evolución postvaríscica de la cordillera cántabro-astúrica. Publicaciones Extranjeras de Geología de España 3, 104-224, Madrid 1946).

Koechlin, E. (1942): Pseudocyclammina virguliana n. sp. aus den Virula-Mergeln des Berner Jura. Eclogae geologicae Helvetiae 35, 195 199.

Lepvrier, C., Martínez-García, E. (1990): Fault development and stress evolution of the post-Hercynian Asturian Basin (Asturias and Cantabria, northwestern Spain). Tectonophysics 184 (3-4), 345-356. doi: 10.1016/0040-1951(90)90447-G.

Loeblich, A., Tappan, H. (1987): Foraminiferal Genera and Their Classification. Van Nostrand Reinhold Company, New York, 2 vol., 970 p.

Mas, R., García, A., Salas, R., Meléndez, A., Alonso, A., Aurell, M., Bádenas, B., Benito, M.I., Carenas, B., García-Hidalgo, J.F., Gil, J., Segura, M. (2004): Segunda fase de rifting: Jurásico Superior Cretácico Inferior. In: J.A. Vera, J.A. (ed.). Geología de España. Sociedad Geológica de España-Instituto Geológico y Minero de España, Madrid, 503-510.

Maync, W. (1949): The foraminiferal genus Choffatella in the Lower Cretaceous (Urgonian) of the Caribbean region (Venezuela, Cuba Mexico and Florida). Eclogae geologicae Helvetiae 42, 529-547.

Maync, W. (1958): Feurtillia frequens n.gen, n.sp., a new genus of Lituolid foraminifera. Contributions from the Cushmann Foundation for Foraminiferal Research 9, 53-57.

Maync, W. (1959): The foraminiferal genera Spirocyclina and Iberina. Micropaleontology 5, 33-68. doi: 10.2307/1484154.

Neagu, T., Cîrnaru, P. (2004): Genus Choffatella (Schlumberger), 1904
(Foraminifera) in the Lower Aptian (Bedoulian) from Southern Dobrogea (Romanian plain). Acta Palaeontologica Romaniae 4, 269275.

Oloriz, F., Valenzuela, M., García-Ramos, J.C., Suárez de Centi, C. (1988): The first record of the Genus Eurasenia (Ammonitina) from the Upper Jurassic of Asturias (Northern Spain). Geobios 21, 741748. doi: 10.1016/S0016-6995(88)80091-3.

Ornelas, M., Hottinger, L. (2006). Upper Jurassic Lituolids in the Sierra de Chiapas (México) and the relation to the Tethys. Anuário do Instituto de Geosciencias 29, 351-352.

Pujalte, V., Robles, J.C., García-Ramos, J.C., Hernández, J.M. (2004): El Malm-Barremiense no marinos en la Cordillera Cantábrica. In: J.A. Vera, J.A. (ed.). Geología de España. Sociedad Geológica de España-Instituto Geológico y Minero de España, Madrid, 288-291.

Ramalho, M. (1971): Contribution à l'étude micropaléontologique et stratigraphique du Jurassique supérieur et du Crétacé inférieur des environs de Lisbonne (Portugal). Serviços Geologicos de Portugal, Memoria 19 (Nova serie), 212 pp.

Ramírez del Pozo, J. (1969): Bioestratigrafía y paleogeografía del Jurásico de la costa asturiana (zona de Oviedo, Gijón, Villaviciosa). Boletín Geológico y Minero 80 (4), 307-332.

Ramírez del Pozo, J. (1971): Bioestratigrafía y microfacies del Jurásico y Cretácico del Norte de España (Región Cantábrica). Memorias del Instituto Geológico y Minero de España, Madrid, 357 pp.

Rat, P. (1959): Les pays crétacés basco-cantabriques (Espagne). PhD Faculté Sciences de Dijon (France), 525 pp.

Redmond, C. (1964): Lituolid foraminifera from the Jurassic and Cretaceous of Saudi Arabia. Micropaleontology 10, 405-414. doi: $10.2307 / 1484643$.

Redmond, C. (1965): Three new genera of foraminifera from the Jurassic of the Saudi Arabia. Micropaleontology 11, 1333-140. doi:10.2307/1484514.

Robles, S., Pujalte, V., Hernández, J.M., Quesada, S. (1996): La sedimentación aluvio-lacustre de la Cuenca de Cires (Jurásico sup.-Berriasiense de Cantabria): un modelo evolutivo de las cuencas lacustres ligadas a la etapa temprana del rift noribérico. Cuadernos de Geología Iberica 21, 227-251.

Schroeder, R., Wienands, A.K. (1966): Über die marine Unterkreide der asturischen Küste (Nord- Spanien). Neues Jarbuch für Geologie und Paläontologie Abhandhungen 117, 346-359.

Schudack, U., Schudack, M. (2002): New biostratigraphical data for the upper Jurassic of Asturias (Northern Spain) based on ostracoda. Revista Española de Micropaleontología 34 (1), 1-18.

Septfontaine, M. (1987): Vers une classification évolutive des Lituolidés (Foraminifperes) jurasiques en milieu de plate-forme carbonatée. Revue de Paléobiologie 2, Benthos'86, 229-256.

Sigal, J. (1959): Trimorphisme morphologique et trimorphisme structural. Un exemple: Choffatella decipiens Schlumberger 1905, Foraminifère. Bulletin de la Societé Géologique de France 7 (1), p.662.

Suárez Vega, L.C. (1974): Estratigrafía del Jurásico en Asturias. Cuadernos de Geología Ibérica 3: 1-369.

Valenzuela, M., García-Ramos, J.C., Suárez de Centi, C. (1986): The Jurassic sedimentation in Asturias (N Spain). Trabajos de Geología $16,121-132$.

Whittaker, J.E., Jones, R.W., Banner, F.T. (1998): Key Mesozoic benthic Foraminifera of the Middle East. The Natural History Museum, $107 \mathrm{pl}$.

Wimbledon, W. A. P., Carellato, C. E., Reháková, D., Bylot, L. G., Erba, E., Gardin, S., Verreussel, R.M. C. M., Munsterman, .K., Hunt, C. O., Fixing a basal Berriassian and Jurassic-Cretaceous (J-K) boundary is there perhaps some light at the end of the tunnel? Rivista Italiana di paleontologia e Stratigrafia 117, 295-307.

Virgili, C., Suárez, L.C., De la Vega, J., Cadavieco, J. (1968): Un nivel de calizas de algas en el Jurásico superior asturiano. Acta Geologica Hispanica 3 (5), 117-119. 


\section{APPENDIX}

\section{Foraminifera}

Anchispirocyclina lusitanica (Egger, 1902) (=Dicyclina lusitanica Egger, p. 585-586, pl. 6, Fig. 3-5).

Andersenolina gr. alpina (Leupold, 1935)(=Coscinoconus alpinus Leupold in Leupold \& Bigler, 1935: 610, pl. 18, Figs. 1-11). Alveosepta Hottinger, 1967 (Type species: Cyclammina jaccardi Schrodt, 1894).

Choffatella decipiens Schlumberger, 1905, p. 763-764, pl. 28, Figs. 1-6.

Choffatella aff. tingitana Hotttinger, 1967, p. 65, text-figs. 4, 32 F-N, pl. 14, Fig. 1-22.

Everticyclammina virguliana (Koechlin, 1942)(=Pseudocyclammina virguliana Koechnin, p. 195-199, pl. 6, Fig. 1-7).

Feurtillia frequens Maync, 1958, p. 1-3, pl. 1, Figs. 1-9, pl. 2, Figs. 1-10.

Mohlerina bassilensis (Mohler, 1938) (="Conicospirina" bassiliensis Mohler, p. 27, pl. 4, Figs. 4-5).

Nautiloculina cf. oolithica Mohler, 1938, p. 19, pl. 4, Figs. 1-3.

Orbitolina (Mesorbitolina) texana (Roemer, 1849) (= Orbitulites texanus Roemer, p. 392).

Palorbitolina lenticularis (Blumenbach, 1805) (=Madreporites lenticularis Blumenbach, p. 13.

Pseudocyclammina lituus (Yokoyama, 1890) (=Cyclammina lituus Yokoyama, p. 26, pl. 5, Fig. 7).

Pseudocyclammina sphaeroidalis Hottinger, 1967, p. 57, text-fig. 29c, pl. 10, Fig. 14-17.

Rectocyclammina chouberti Hottinger, 1967, p. 55, text-figs. 26, 27 a-c, pl. 9, Figs. 19-21.

Sabaudia minuta (Hofker, 1965) (= Textulariella minuta Hofker, p. 186-187, pl. 3, Figs. 5-6, pl. 4, Figs. 1-9).

\section{Calcareous Algae}

Marinella lugeoni Pfender, 1939, p. 3-5, pl. 2, Fig. 1-2.

Cayeuxia piae Frollo, 1939 p. 269-271, pl. 18, Figs B1-B.

Salpingoporella annulata Carozzi, 1953, p. 382-386, text-fig. 1-55. 